\title{
Protein diagenesis in Patella shells: Implications for amino acid racemisation dating
}

\author{
José E. Ortiz ${ }^{\mathrm{a},}{ }^{*}$, Igor Gutiérrez-Zugasti ${ }^{\mathrm{b}}$, Trinidad Torres ${ }^{\mathrm{a}}$, Manuel González-Morales ${ }^{\mathrm{b}}$, \\ Yolanda Sánchez-Palencia ${ }^{\mathrm{a}}$ \\ a Laboratory of Biomolecular Stratigraphy, E.T.S.I. Minas, Universidad Politécnica de Madrid, C/ Ríos Rosas 21, Madrid 28003, Spain \\ ${ }^{\mathrm{b}}$ Instituto Internacional de Investigaciones Prehistóricas de Cantabria, Facultad de Filosofia, Universidad de Cantabria, Avda de los Castros s/n, 39005 \\ Santander, Spain
}

\begin{abstract}
A B S T R A C T
The inter- and intra-crystalline fractions of Patella vulgata limpets recovered from archaeological sites in Northern Spain (covering Neolithic, Mesolithic, Magdalenian, Solutrean, and Aurignacian periods) were examined for amino acid composition and racemisation over time. The calcitic apex and rim areas of the shells were found to probably be composed of similar proteins, as the $\mathrm{D} / \mathrm{L}$ values and amino acids were comparable and varied in the same way with increasing age; however, the mineral structures present in these areas differed. The aragonitic intermediate part of the shell showed a distinctly different amino acid composition and mineral structure. The main protein leaching from the inter-crystalline fraction occurred within the first $6000 \mathrm{yr}$ after the death of the organism. In contrast, the intra-crystalline fraction - comprised of a different protein composition than the inter-crystalline fraction - appeared to behave as a closed system for at least $34 \mathrm{ka}$, as reflected by the lack of a significant decrease in the amino acid content; however, changes in the amino acid percentages occurred during this period. The concentration of aspartic acid remained almost constant with age both in inter- and intra-crystalline proteins, and its contribution to the total amino acid content increased with age at the expense of other amino acids such as glutamic acid, serine, glycine and alanine. Temperature is thought to play a key role in the amino acid racemisation of $P$. vulgata and could explain why in the localities belonging to the Gravettian and Solutrean period, which formed during relatively cold conditions, D/L values were similar to those detected in shells from sites formed during the Magdalenian.
\end{abstract}

\section{Introduction}

The first attempts to establish the chronology of shell middens using amino acid racemisation/epimerisation date back to the 1970s when Masters and Bada (1977) and Wehmiller (1977) analysed marine bivalve molluscs (Chione) from California. Several studies have demonstrated that amino acid racemisation (AAR) is a satisfactory tool for dating palaeontological and archaeological sites, including the use of limpets recovered from Palaeolithic and Mesolithic anthropogenic shell middens (Bateman et al., 2008; Ortiz et al., 2009a; Demarchi et al., 2011). Shell middens often accumulate relatively rapidly but they are subject to complex taphonomy. Consequently, large sample sizes for dating are

\footnotetext{
* Corresponding author.

E-mail address: joseeugenio.ortiz@upm.es (J.E. Ortiz).
}

required to resolve issues of intra-site chronology (e.g. Glover et al., 1990; Stein and Deo, 2003). The number of samples commonly used for the age calculation of a single level through AAR allows not only the rejection of anomalous results, but also an understanding of time-averaging and the time over which a certain site formed.

Some uncertainties regarding the protein diagenesis of limpet shells remain. Further research is therefore required to clarify the processes of protein preservation and degradation and the concomitant success of AAR for dating archaeological localities. Recent studies of modern limpets performed by Demarchi et al. (2011, 2013a,b) showed the potential of intra-crystalline proteins in Patella shells for AAR geochronology. In these studies, artificial diagenesis was induced in proteins (both inter- and intracrystalline protein fractions, and the isolated intra-crystalline fraction) of modern Patella shells through high-temperature experiments $\left(80^{\circ}, 110^{\circ}\right.$, and $\left.140^{\circ} \mathrm{C}\right)$ over a range of times $(0-5738 \mathrm{~h})$. The protein breakdown was quantified by measuring the extent 
and racemisation of various amino acids. This provided data on protein diagenesis in modern limpets; however, it is pertinent to reveal the circumstances of protein degradation in fossil representatives. In this regard, here we examined the amino acid content and $\mathrm{D} / \mathrm{L}$ values in limpets (Patella vulgata) collected from several archaeological sites of known ages (dated by ${ }^{14} \mathrm{C}$ ) covering the Aurignacian (ca. 34 cal. ka BP), Gravettian (ca. 27.5 cal. ka BP), Solutrean (ca. 26.5-20.5 ka cal. BP), Lower, Middle and Upper Magdalenian (20.5-12.0 cal. ka BP), Azilian (ca. 12.0-10.8 cal. ka BP), Mesolithic-Asturian (10.8-6.3 cal. ka BP), and Neolithic (ca. 6.3-5.8 cal. ka BP) periods. P. vulgata was chosen because this limpet is the most common species in shell middens in Northern Spain (González-Morales, 1982; Bailey and Craighead, 2003; Gutiérrez-Zugasti, 2009, 2011; Álvarez-Fernández, 2011). We examined the behaviour of the whole protein content (interand intra-crystalline proteins) and the intra-crystalline fraction separately, the latter by bleaching prior to analysis.

Several studies (Haugen and Sejrup, 1992; Wehmiller, 1993; Torres et al., 1999) have reported intra-shell variation of $\mathrm{D} / \mathrm{L}$ values depending on the part of the carapace from which the sample is recovered. We therefore also studied the amino acid content and $\mathrm{D} / \mathrm{L}$ values of two parts of the shell (apex and rim) in samples of various ages.

\section{Material and methods}

The samples were collected from 12 sites in the regions of Asturias and Cantabria (Northern Spain) previously excavated in archaeological campaigns (Fig. 1). Permission was obtained for sampling the limpets. Once collected, the shells were stored at the "Museo Arqueológico de Asturias", the "Museo de Prehistoria y Arqueología de Cantabria", and the "Museo y Centro de Investigación de Altamira". Limpets were cleaned with water after their collection and stored in boxes at room temperature $\left(15^{\circ} \mathrm{C}\right)$ in the museums. The coordinates of the localities are reported in Table 1 (Fig. 1), together with the time period of the archaeological level sampled.

P. vulgata shells from the levels belonging to the Upper Palaeolithic (Aurignacian, Gravettian, Solutrean, Magdalenian, Azilian), Mesolithic (Asturian) and Neolithic (Table 1) periods were analysed for AAR. For comparitive purposes, modern specimens were recovered from Cue beach (Asturias), located close to the archaeological localities (Fig. 1).

\subsection{Petrographic analysis}

Selected $P$. vulgata shells from modern individuals were cut into thin sections along their major axis and placed on microscope slides. To determine the distribution of minerals and the organic matrix, the sections were submerged in Feigl's and Mutvei's solutions for 5 min and observed under a Nikon microscope.

To distinguish between the two calcium carbonate polymorphs that mollusc shells generally form, we applied Feigl's solution, which was prepared following Feigl (1937, in Friedman, 1959). This procedure stained aragonite crystals black, while calcite ones remain unstained.

To highlight the organisation of the organic matrix and the crystal arrangement, we used Mutvei's solution (Mutvei et al., 1994), following the modifications described by Schöne et al. (2005): one litre of Mutvei's solution consists of $500 \mathrm{ml} \mathrm{1 \%}$ acetic acid, $500 \mathrm{ml} 25 \%$ glutaraldehyde and ca. 5-10 g Alcian blue powder. The use of Mutvei's solution facilitates the identification of microgrowth structures in carbonates of biogenic origin by staining organic matrix laminae and crystal envelopes in shades of blue.

\subsection{Amino acid racemisation}

Between 4 and $11 P$. vulgata shells (analytical samples) from each archaeological level were analysed for amino acids. The use of monospecific or monogeneric samples reduces taxonomicallycontrolled variability in D/L values (Murray-Wallace, 1995; Murray-Wallace and Goede, 1995). In the laboratory, shells were

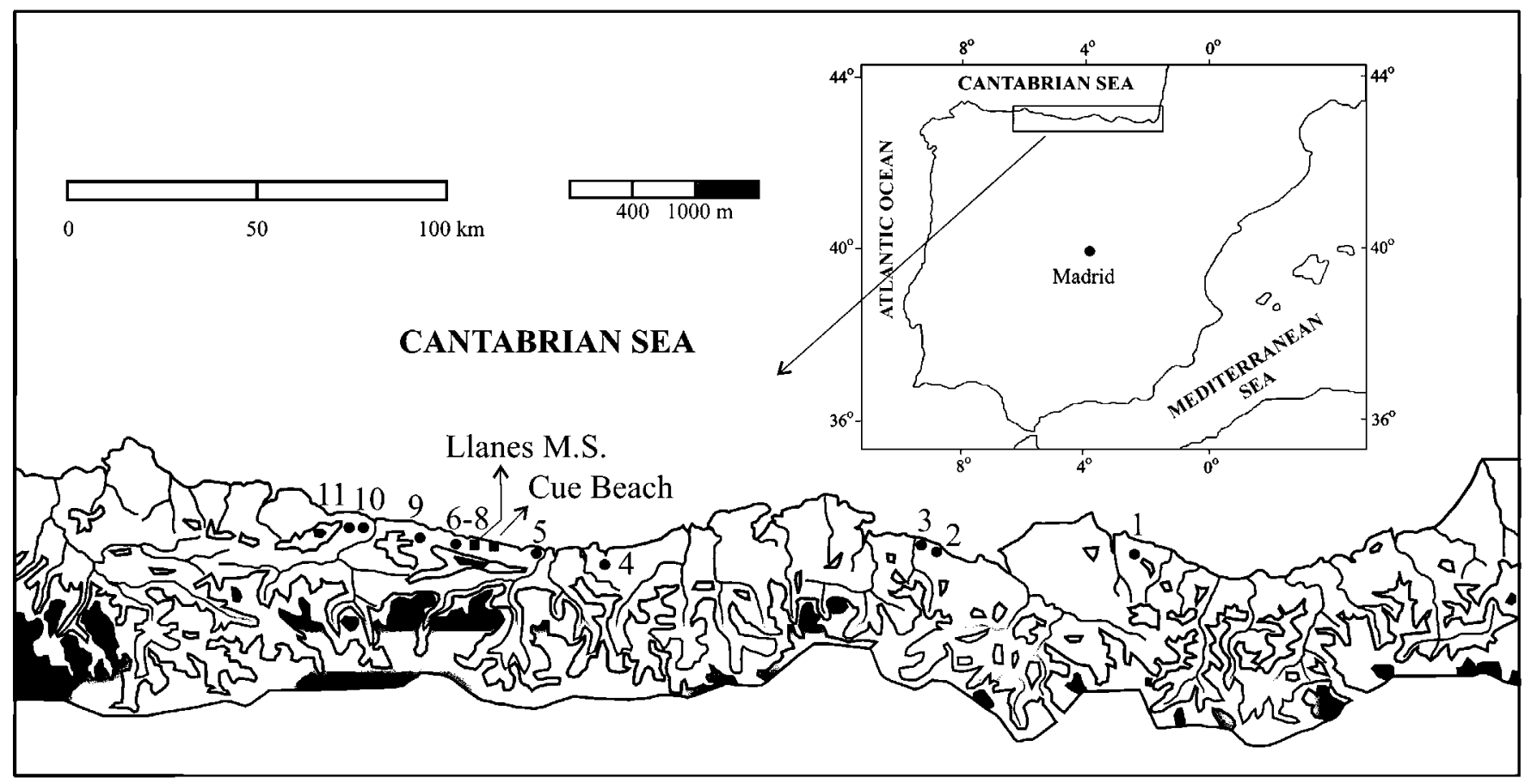

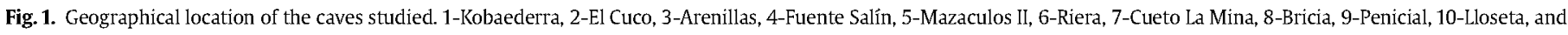
11-Les Pedroses. Cue beach and Llanes meteorological station were also plotted. 
Table 1

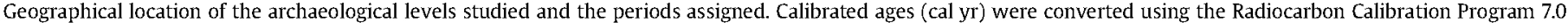
(CALIB 7.0) (Stuiver et al., 2014) with the calibration dataset IntCal13 (Reimer et al., 2013). Original radiocarbon ages are in Table 1-Supplementary information.

\begin{tabular}{|c|c|c|c|c|c|}
\hline Cave & Latitude & Longitude & $\begin{array}{l}\text { Elevation } \\
\text { a.s.l. (m) }\end{array}$ & Archaeological level & Age (cal. yr BP) \\
\hline Cue beach & $43^{\circ} 25^{\prime} 4^{\prime \prime} \mathrm{N}$ & $4^{\circ} 43^{\prime} 45^{\prime \prime} \mathrm{W}$ & 0 & - & Modern \\
\hline $\begin{array}{l}\text { Kobaederra } \\
(\mathrm{KBR})\end{array}$ & $43^{\circ} 20^{\prime} 35^{\prime \prime} \mathrm{N}$ & $2^{\circ} 37^{\prime} 3^{\prime \prime} \mathrm{W}$ & 260 & Level 2 & $\begin{array}{l}\text { Neolithic [1] } \\
5975 \pm 160(\text { UBAR-472) }\end{array}$ \\
\hline $\begin{array}{l}\text { Arenillas } \\
\text { (ARE) }\end{array}$ & $43^{\circ} 23^{\prime} 44^{\prime \prime} \mathrm{N}$ & $3^{\circ} 18^{\prime} 46^{\prime \prime} \mathrm{W}$ & 20 & Shell midden & $\begin{array}{l}\text { Asturian [2] } \\
6385 \pm 70(\mathrm{GrN}-19596)\end{array}$ \\
\hline $\begin{array}{l}\text { Bricia } \\
\text { (BRI) }\end{array}$ & $43^{\circ} 25^{\prime} 38.2^{\prime \prime} \mathrm{N}$ & $4^{\circ} 51^{\prime} 17.8^{\prime \prime} W$ & 50 & $\begin{array}{l}\text { Shell midden (Level A [5]) } \\
\text { Level C [5] }\end{array}$ & $\begin{array}{l}\text { Asturian [3,4] } \\
7680 \pm 150 \text { (GaK 2908) } \\
\text { Upper Magdalenian [3] }\end{array}$ \\
\hline \multirow{9}{*}{$\begin{array}{l}\text { Mazaculos II } \\
\text { (MAZ) } \\
\text { La Riera } \\
\text { (RIE) }\end{array}$} & $43^{\circ} 23^{\prime} 26^{\prime \prime} \mathrm{N}$ & $4^{\circ} 34^{\prime} 43^{\prime \prime} \mathrm{W}$ & 35 & Shell midden Level 1.3 & $\begin{array}{l}\text { Asturian [6] } \\
8490 \pm 40 \text { (UGAM-9081) }\end{array}$ \\
\hline & $43^{\circ} 25^{\prime} 26.86^{\prime \prime} \mathrm{N}$ & $4^{\circ} 50^{\prime} 53.63^{\prime \prime} \mathrm{W}$ & 35 & Shell midden 29 & $\begin{array}{l}\text { Asturian [3] } \\
7375 \pm 185(\mathrm{GaK}-3046)\end{array}$ \\
\hline & & & & $\begin{array}{l}\text { Level } 27 \text { upper } \\
\text { Level } 24\end{array}$ & $\begin{array}{l}\text { Azilian/Magdalenian[7] } 12,510 \pm 195 \\
\text { (BM-1494); } 17,960 \pm 490(\text { GaK-6985) } \\
\text { Upper Magdalenian [7] } 12,660 \pm 545 \\
\text { (GaK-6982) }\end{array}$ \\
\hline & & & & Level 23 & $\begin{array}{l}\text { Upper Magdalenian [7] } \\
11,945 \pm 730(\text { Ly-1646) }\end{array}$ \\
\hline & & & & Level 18.1 & $\begin{array}{l}\text { Lower Magdalenian [7] } \\
18,430 \pm 530(\mathrm{Q}-2116) ; \\
18690 \pm 490(\mathrm{Q}-2110) ; 19,680 \pm 555 \\
(\text { GaK-6448) }\end{array}$ \\
\hline & & & & Level 16 & $\begin{array}{l}\text { Solutrean [7] } \\
21,750 \pm 770(\text { GaK-6983) }\end{array}$ \\
\hline & & & & Level 10 & $\begin{array}{l}\text { Solutrean [7] } \\
23,690 \pm 565(\text { GaK-6447) }\end{array}$ \\
\hline & & & & Level 8 & $\begin{array}{l}\text { Solutrean [7] } \\
24810 \pm 1055(\mathrm{GaK}-6981) \\
19,090 \pm 350(\text { GaK-6450) }\end{array}$ \\
\hline & & & & Level 1 & $\begin{array}{l}\text { Pre-Solutrean [7] } \\
23485 \pm 550(\text { UCR-1270) } \\
24285 \pm 565(\text { Ly-1783); } 24,285 \pm 525 \\
\text { (BM-1739) }\end{array}$ \\
\hline $\begin{array}{l}\text { El Penicial } \\
\text { (PEN) }\end{array}$ & $43^{\circ} 26^{\prime} 42.9^{\prime \prime} \mathrm{N}$ & $4^{\circ} 56^{\prime} 22.3^{\prime \prime} \mathrm{W}$ & 60 & Surface shell midden & $\begin{array}{l}\text { Asturian }[3,8] \\
9760 \pm 250(\mathrm{GaK} 2906)\end{array}$ \\
\hline $\begin{array}{l}\text { Les Pedroses } \\
\text { (LPS) }\end{array}$ & $43^{\circ} 27^{\prime} 26.6^{\prime \prime} \mathrm{N}$ & $5^{\circ} 6^{\prime} 17.7^{\prime \prime} \mathrm{W}$ & 80 & $20 \mathrm{~cm}$ thick level & Lower Magdalenian $[3,9]$ \\
\hline $\begin{array}{l}\text { La Lloseta } \\
\text { (LLO) }\end{array}$ & $43^{\circ} 27^{\prime} 38.3^{\prime \prime} \mathrm{N}$ & $5^{\circ} 4^{\prime} 29.1^{\prime \prime} \mathrm{W}$ & 40 & Level B (sample A) & $\begin{array}{l}\text { Middle Magdalenian [3] } \\
18,340 \pm 280(\text { GaK 2549) }\end{array}$ \\
\hline $\begin{array}{l}\text { Fuente del } \\
\text { Salín } \\
\text { (FTS) }\end{array}$ & $43^{\circ} 22^{\prime} 7^{\prime \prime} \mathrm{N}$ & $4^{\circ} 28^{\prime} 52^{\prime \prime} \mathrm{W}$ & 10 & Level $2 / 3$ & $\begin{array}{l}\text { Gravettian[10] } \\
26,850 \pm 775(\mathrm{GrN}-18574) \\
27,315 \pm 385(\mathrm{GX}-27756)\end{array}$ \\
\hline $\begin{array}{l}\text { El Cuco } \\
\text { (CUC) }\end{array}$ & $43^{\circ} 23^{\prime} 28^{\prime \prime} \mathrm{N}$ & $3^{\circ} 13^{\prime} 40^{\prime \prime} \mathrm{W}$ & 25 & Level XIII & $\begin{array}{l}\text { Aurignacian [11] } \\
34,290 \pm 160(\text { GrA } 32436)\end{array}$ \\
\hline
\end{tabular}

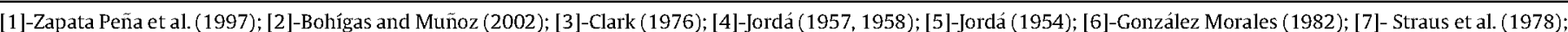
Straus and Clark (1986); [8]-Vega del Sella (1914); [9]-Hernández-Pacheco et al. (1957); [10]-Moure and González Morales, 1992; [11]-Muñoz Fernández et al. (2007).

carefully sonicated and cleaned with water to remove sediment. Peripheral parts, approximately 20-30\%, were removed after chemical cleaning of the sample with $2 \mathrm{~N} \mathrm{HCl}$.

For all samples, we drilled a small disc in the apex of the shells, which has been shown to reduce variability (cf. Murray-Wallace, 1995). This selection was also based on the results from the petrographic analysis, which showed that the apex was made of calcite (cf. MacClintock, 1967; Fenger et al., 2007; Ortiz et al., 2009a; Demarchi et al., 2013a). In addition, we sampled the rim, also made of calcite, in the same limpets (with the exception of those from La Riera cave) in order t test intra-shell variation. The intermediate part of the shell was also sampled, but only in modern limpets. $c a$. 5-20 $\mathrm{mg}$ of apex and rim areas was subjected to AAR analysis of the total protein content (inter- and intra-crystalline proteins). Samples from the apex were also used to measure the amino acids in the intra-crystalline fraction after bleaching.

\subsubsection{Bleaching}

Powdered shell samples from the apex of the same limpets used to analyse the total protein content were used for the isolation of intra-crystalline proteins. The shell particles measured less than $500 \mu \mathrm{m}$, following Demarchi et al. (2013a), a size for which bleaching is most effective. In this regard, we exposed these powdered samples to $10 \%$ sodium hypochlorite $(\mathrm{NaOCl})$, an effective oxidising agent for this purpose (Penkman et al., 2008; Demarchi et al., 2013a). Samples were exposed to $\mathrm{NaOCl}$ for $48 \mathrm{~h}$, a time reported to be the optimal bleaching period for $P$. vulgata (Demarchi et al., 2013a), although they used a NaOCl concentration of $12 \%$.

For each fraction, $50 \mu \mathrm{l}$ of $\mathrm{NaOCl}$ per mg of powdered shell was added to accurately weighed subsamples at room temperature. To ensure the complete penetration of the oxidising agent, the vials containing the powders and the bleach were shaken every $24 \mathrm{~h}$. The bleach was then removed, and the powders were rinsed five times in ultrapure water and once in HPLC-grade methanol, with centrifugation or $4 \mathrm{~min}$ between each rinse to minimise the removal of powder. Finally, the samples were air-dried overnight.

\subsubsection{Amino acid analysis}

Amino acid concentrations and racemisation/epimerisation 
ratios were quantified using a HPLC, following the sample preparation protocol described in Kaufman and Manley (1998) and Kaufman (2000). This procedure involves hydrolysis, which was performed under an $\mathrm{N}_{2}$ atmosphere in $20 \mu \mathrm{L} / \mathrm{mg}$ of $7 \mathrm{M} \mathrm{HCl}$ for $20 \mathrm{~h}$ at $100{ }^{\circ} \mathrm{C}$. The hydrolysates were evaporated to dryness in vacuo and then rehydrated in $10 \mu \mathrm{L} / \mathrm{mg}$ of $0.01 \mathrm{M} \mathrm{HCl}$ with $1.5 \mathrm{mM}$ sodium azide and $0.03 \mathrm{mM}$ L-homo-arginine (internal standard).

Samples were injected into an Agilent HPLC-1100 equipped with a fluorescence detector. Excitation and emission wavelengths were programmed at $335 \mathrm{~nm}$ and 445 , respectively. A Hypersil BDS C18 reversephase column ( $5 \mu \mathrm{m} ; 250 \times 4 \mathrm{~mm}$ i.d.) was used for the analysis.

Derivatisation was achieved before injection by mixing the sample $(2 \mu \mathrm{l})$ with the pre-column derivatisation reagent $(2.2 \mu \mathrm{l})$, which comprised $260 \mathrm{mM}$ isobutyryl-L-cysteine (chiral thiol) and $170 \mathrm{mM}$ o-phtaldialdehyde, dissolved in a $1.0 \mathrm{M}$ potassium borate buffer solution at $\mathrm{pH} 10.4$. Eluent $\mathrm{A}$ consisted of $23 \mathrm{mM}$ sodium acetate with $1.5 \mathrm{mM}$ sodium azide and $1.3 \mathrm{mM}$ EDTA, adjusted to pH 6.00 with $10 \mathrm{M}$ sodium hydroxide and $10 \%$ acetic acid. Eluent B was HPLC-grade methanol, and eluent $C$ consisted of HPLC-grade acetonitrile. A linear gradient was performed at $1.0 \mathrm{~mL} / \mathrm{min}$ and $25{ }^{\circ} \mathrm{C}$, from $95 \%$ eluent $\mathrm{A}$ and $5 \%$ eluent $\mathrm{B}$ upon injection to $76.6 \%$ eluent $A, 23 \%$ eluent $B$, and $0.4 \%$ eluent $C$ at $\min 31$; and then with a progressive gradient at $1.07 \mathrm{~mL} / \mathrm{min}$ and the following percentages: $46.2 \%$ eluent $A, 48.8 \%$ eluent $B$, and $5.0 \%$ eluent $C$ at min 95 . As a laboratory routine, we separated the $D$ and L peaks of the following amino acids (Fig. 1-Supplementary Data): aspartic acid and asparagine (Asx), glutamic acid and glutamine (Glx), serine (Ser), alanine (Ala), valine (Val), phenylalanine (Phe), isoleucine (Ile), leucine (Leu), threonine (Thr), arginine (Arg), and tyrosine (Tyr), together with the abundance of glycine (Gly).

Asx and Glx D/L values obtained by means of HPLC are comparable with those measured with GC as similarities have been reported in inter-laboratory comparison exercises (cf. Wehmiller, 1984; Torres et al., 1997; Wehmiller et al., 2010) and between several samples analysed by GC and HPLC in our laboratory (cf. Ortiz et al., 2009b, p. 955, see Fig. 2-Supplementary Data).

\subsubsection{Data screening of the AAR analyses}

A total of 121 powdered samples taken from the apex of $P$. vulgata shells were analysed for amino acid content. The same 121 samples were also used for the bleaching experiment. Rim samples of 76 of these limpets were also used to determine their amino acid composition (samples from the levels of La Riera Cave were not used because we obtained permission to take samples only from the apex).

Of these, 14 results $(11.6 \%$ of the data- 1 in Kobaederra, 3 in Arenillas, 2 in Mazaculos II, 1 in El Penicial, 1 in Bricia-B, 3 in El Cuco, 2 in level 24 of La Riera, and 1 in level 23 of La Riera 5) were excluded due to Asx and Glx D/L values that fall off the covariance trend (cf. Kaufman, 2003, 2006; Laabs and Kaufman, 2003) (Figs. 3-5 Appendix) and/or because of abnormally high $\mathrm{D} / \mathrm{L}$ values, characterised by Asx D/L and Glx D/L values falling outside the $2 \sigma$ range of the group (cf. Hearty et al., 2004; Kosnik and Kaufman, 2008). These samples also showed a low amino acid content. $12.4 \%$ of the data from bleached apex samples, and $11.8 \%$ from unbleached rim samples were also excluded, coinciding in most cases with outliers from unbleached apex. It is possible that these samples with high D/L values were anthropogenically-heated. Each result and the samples rejected are shown in the Appendix. The data used in the following sections is only from the screened samples, not including outliers.

\subsection{Temperature within the sediment of archaeological sites}

As AAR is a temperature-dependent process, we attempted to observe the influence of atmospheric temperature inside the archaeological sites. For this purpose, permission was obtained from the Communities of Asturias and Cantabria to bury Hobo UA001-64 digital thermometers between 10 and $15 \mathrm{~cm}$ inside the sediment at the entrance to some of the caves where the remains were collected (El Cuco, Arenillas, El Perro, Mazaculos II, La Riera, Bricia, El Penicial, and La Lloseta). These devices were programmed to register temperature at 4-h intervals and data was collected over 1 year (January to December 2013).

\section{Intrashell variations}

\subsection{Petrographic analysis}

As observed previously (MacClintock, 1967; Fenger et al., 2007; Ortiz et al., 2009a; Demarchi et al., 2013a), calcite was the main component of the apex and rim of modern and archaeological representatives. These shell areas remained unstained after submerging the thin sections in the Feigl dye (Fig. $2 \mathrm{~A}$ and $\mathrm{B}$ ), which corresponded to layers $\mathrm{M}+3, \mathrm{M}+2$ and $\mathrm{M}-2$ according to the terminology of MacClintock (1967), $M$ being the myostracum (muscle attachment site). In contrast, the intermediate area (layers $M+1, M, M-1$ ) was stained black, indicating that it was made of aragonite (Fig. 2A and B). Similar to the findings of MacClintock (1967) and Demarchi et al. (2013a), we found that the outer aragonite layer did not occupy a significant portion of the shell.

of note, the boundary between the calcitic M-2 layer and the aragonitic $M-1$ layer was not straight but showed an interfingering relationship between the two layers (Fig. 2A). This relationship was also observed when the shells were stained with Mutvei's solution (Fig. 2C). This dye revealed major and minor growth lines of biogenic carbonate, both in the calcitic and aragonitic dominions, which were parallel to the shell surface. Major growth lines in the cross-sections were identified as thicker, more pronounced lines, and these were more clearly observed in layers $M+1, M-1$ and $M-2$ (Fig. 2C and D). Minor growth lines, representing semidiurnal and lunar growth increments (Fenger et al., 2007), were extremely fine and detected only at high magnification (Fig. 2E).

Mutvei's solution also showed an irregular distribution of organic matter through the shell section, as revealed by a strong stain in the calcitic apex $(M-2)$ and $\operatorname{rim}(M+3, M+2)$, thus indicating stripes rich in organic matter. In contrast, aragonitic intermediate parts $(M+1, M-1)$ were a brownish colour. In most cases, the outermost $\mathrm{M}+3$ and $\mathrm{M}+2$ layers were not clearly distinguishable, as also reported in Forli et al. (2004).

The myostracum was very thin and showed a prismatic structure with large crystals oriented perpendicular to the shell surface (Fig. 2D). In the closest interior and external areas to the myostracum ( $M-1, M+1$ respectively), namely the aragonitic intermediate part, we observed a complex crossed-lamellar structure consisting of complicated hierarchical structural (first-, secondand third-order lamellar structures) features with a feather-like pattern, in which the fibres are oriented perpendicular to the surface of the shell (Fig. 2E and G). Consistent with observations by MacClintock (1967) and Cohen and Branch (1992), we found that the aragonitic $\mathrm{M}-1$ layer was very thin (Fig. $2 \mathrm{D}$ and $\mathrm{E}$ ).

In contrast, the microstructure of the $\operatorname{rim}(\mathrm{M}+3, \mathrm{M}+2$ layers $)$ showed a concentric crossed-lamellar pattern with crystal aggregates arranged parallel to the shell margin, although in these layers $(\mathrm{M}+2$ and $\mathrm{M}+3)$ they then became gradually oblique to the outer surface, with a progressive twist to $90^{\circ}$ of first order lamella (Fig. 2D, E, F, H), although columnar in appearance. The apex, which was occupied by layer $\mathrm{M}-2$, showed a microstructure with an irregular to radial crossed-lamellar pattern (Fig. 2C).

In agreement with Watabe (1984) and Cohen and Branch (1992), 

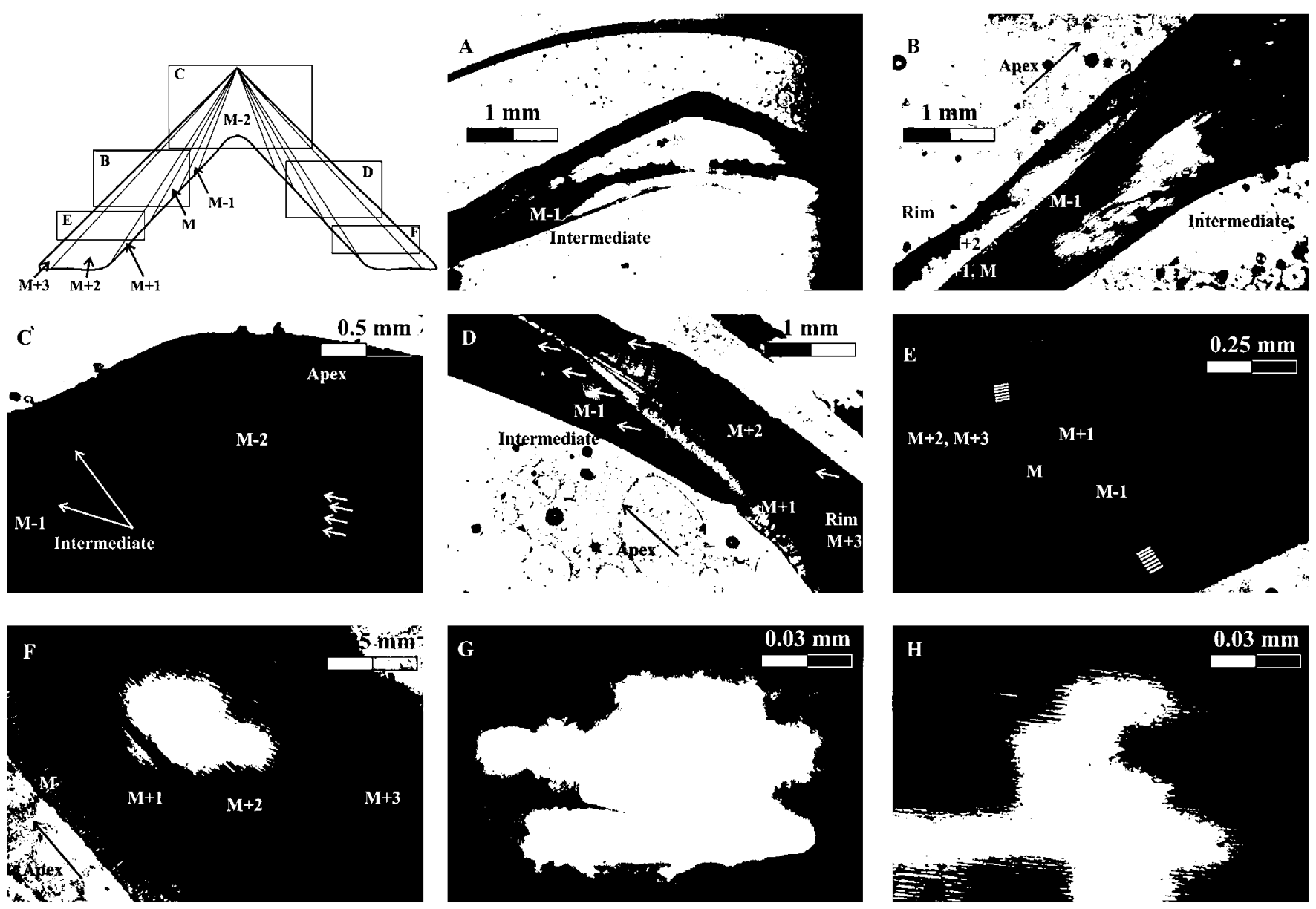

Fig. 2. Microphotographs of thin sections of $P$. vulgata shells treated with Feigl's (A and B) and Mutvei's (C-F) solution (Feigl's solution stained aragonite crystals black, while calcite ones remain unstained; Mutvei's solution stained organic matrix laminae and crystal envelopes in shades of blue). A-cross section of a shell showing the unstained apex area in the central part and the intermediate region stained in black; B-transition between the stained aragonitic intermediate part ( $M-1, M, M+1$ layers) to the unstained rim area ( $M+2$, $M+3$ ); $C$-apex with the $M-2$ layer with an irregular/radial crossed-lamellar pattern and the transition to the $M-1$ layer (major growth lines are marked with arrows) stained in blue; D-contact between the intermediate part (M-1, M+1) with a complex crossed-lamellar structure and the rim ( $M+2, M+3$ layers) with a concentric crossed-lamellar pattern (major growth lines are marked with arrows); E-detail view of the rim area $(\mathrm{M}+2, \mathrm{M}+3$ layers) and the $\mathrm{M}+1, \mathrm{M}$, and $\mathrm{M}-1$ layers (minor growth lines are marked with arrows); F-detailed view of the rim area ( $\mathrm{M}+2, \mathrm{M}+3$ layers), which shows a concentric crossed-lamellar pattern, the aragonitic $\mathrm{M}+1$ layer, which shows complex crossedlamella, and the $\mathrm{M}$ layer, which shows a prismatic structure with large crystals oriented perpendicular to the shell surface; G-detailed view of the complex crossed-lamellar structure of the $\mathrm{M}-1$ layer; H-detailed view of the concentric crossed-lamellar structure of the $\mathrm{M}+2$ layer. (For interpretation of the references to colour in this figure legend, the reader is referred to the web version of this article.)

the complex crossed-lamellar layers $(M-1, M+1)$ consisted of aragonite, whereas the concentric crossed-lamellar layers $(\mathrm{M}+3$, $\mathrm{M}+2, \mathrm{M}-2$ ) were made of calcite.

In brief, layers $\mathrm{M}+3, \mathrm{M}+2$ and $\mathrm{M}-2$ were made of calcite and rich in organic matter, although showed different microstructural patterns. In contrast, $\mathrm{M}+1, \mathrm{M}$ and $\mathrm{M}-1$ layers consisted of aragonite and contain less organic matter. For AAR we analysed the $M-2$ layer (apex), and $M+3$ and $M+2$ layers (rim). In modern representatives we also analysed the $M+1$ and $M-1$ layers located in the intermediate area.

\subsection{Amino acid $D / L$ values}

\subsubsection{Apex and rim - unbleached}

The mean Asx and Glx D/L values in the rim and apex of 105 bleached and unbleached $P$. vulgata shells from the archaeological levels (after the rejection of samples with abnormally high $\mathrm{D} / \mathrm{L}$ values) are shown in Fig. 3. We selected Asx and Glx because they account for a considerable percentage of the amino acid content in modern shells, as shown by Demarchi et al. (2013a).

The individual Asx D/L values in modern limpets were similar in the apex and rim (Fig. 6-Supplementary Data) corresponding with Demarchi et al. (2013a). A similar pattern was obtained for Asx D/L values in these two areas of the shells from the archaeological localities. Similarly, the mean Glx D/L values in the apex and rim of shells from each site were equivalent (Fig. 3, Fig. 7-Supplementary Data, Table 2- Supplementary Data).

In modern limpets we also analysed the amino acids in the intermediate part of the shell, observing that Asx and Glx D/L values were higher than in the apex and rim (Table 2).

\subsubsection{Apex - bleached}

Asx $\mathrm{D} / \mathrm{L}$ values were lower in bleached than in unbleached samples for the same individual shell (Fig. 3). In contrast, Glx D/L values were higher in bleached samples than in unbleached ones for modern and archaeological localities.

\subsection{Amino acid concentrations}

\subsubsection{Apex and rim-unbleached}

The mean of the total amino acid concentration in unbleached $P$. vulgata shells was higher in the rim than in the apex, at least in 


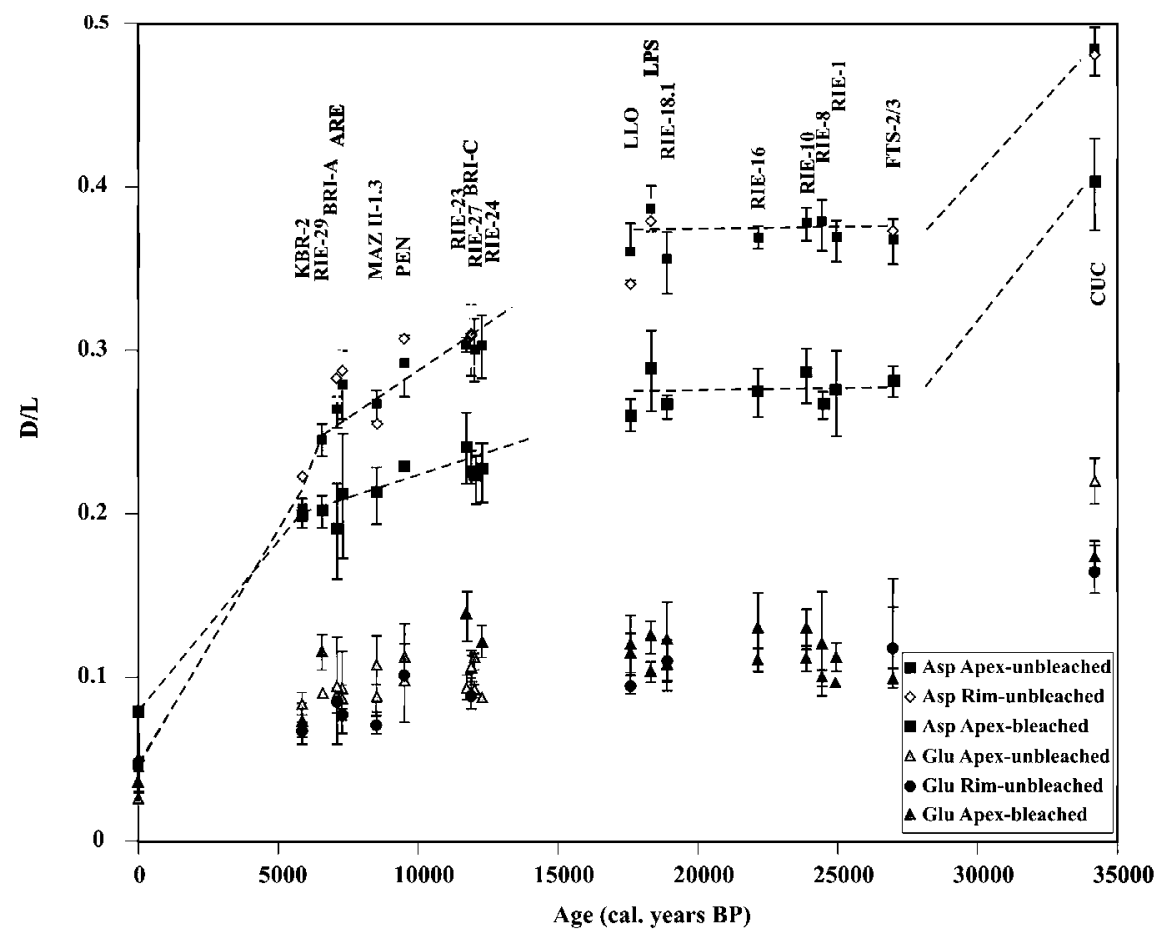

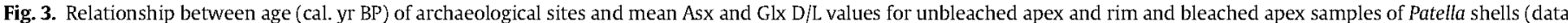
shown in Table 2-Supplementary information). Dashed lines indicate estimated racemisation patterns for Asx in unbleached and bleached apex samples.

modern, Neolithic, and Mesolithic limpets (Fig. 4). In contrast, in Palaeolithic limpets the concentration of amino acids in these areas was more similar to each other. Likewise, there was variability in the amount of amino acids present in shells within the same level.

Similar results were observed for the individual concentrations of Asx ([Asx]) and Glx ([Glx]) (Figs. 5 and 6), two of the most abundant amino acids in limpet shells. Of note, the percentage of each amino acid was similar in the apex and rim areas (Fig. 7).

In modern representatives, the total amino acid content, [Asx], and $[G \mid x]$ were lower in the intermediate parts of shells than in the apex and rim (Table 2). Nevertheless, the percentages of [Asx] and [Glx] in modern specimens were similar to those found in the apex and rim, although the proportion of other amino acids differed (Fig. 8), i.e. \%Ser and \%Gly were lower in the intermediate part than in the apex and rim areas, while \%Ala, \%Val and \%Leu were higher.

\subsubsection{Apex - bleached}

The apex intra-crystalline fraction accounted for around $15 \%$ of the total proteins within a modern limpet shell (Fig. 4). The amino acid composition of inter- and intra-crystalline proteins in the apex of modern and archaeological limpets also differed, as the percentage of [Asx] was higher in unbleached (40\%) than in bleached samples (20-25\%) (Table 3), the percentages of [Glx] and [Gly] being higher in the latter. Similar [Asx] percentages were reported by Demarchi et al. (2013a) for bleached and unbleached modern representatives. However, in some other mollusc shells, the percentage of $[A s x]$ has been reported to increase after bleaching (Penkman et al., 2008).

\subsection{Interpretation of intrashell variations}

\subsubsection{Inter-crystalline fraction}

Here we observed similar Asx D/L values in the unbleached rim and apex sub-samples of modern limpets and archaeological sites (Fig. 3). This observation is reinforced by the finding that the percentage of each amino acid was similar in the apex and the rim, even with increasing age (Fig. 7). This finding indicates that the proteins comprising these regions are probably similar, both areas being made of calcite (cf. MacClintock, 1967; Fenger et al., 2007; Ortiz et al., 2009a; Demarchi et al., 2013a). It must be highlighted that the acidic amino acids (Asx and Glx) accounted for more than half the content of Patella shells. This observation could be associated with the presence of acidic and Asp-rich proteins, which are usually found linked to calcitic structures (Gotliv et al., 2005; Marin et al., 2012). However, we found that the total amino acid content and also the individual concentrations of the two main amino acids (Asx and Glx) in $P$. vulgata shells were higher in the unbleached rim than in the unbleached apex, at least in modern, Neolithic, and Mesolithic limpets (Fig. 4). These results could be attributable to the different mineral structure observed (Fig. 2). Similarly, differential leaching from the unbleached samples may have produced these differences (cf. Penkman et al., 2007, 2008). Likewise, Demarchi

Table 2

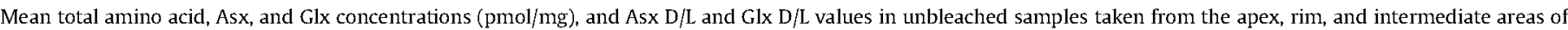
modern $P$. vulgata shells.

\begin{tabular}{|c|c|c|c|c|c|}
\hline Area & [Total] & [Asx] & [Glx] & Asx $D / L$ & Glx D/L \\
\hline Apex & $25462 \pm 6354$ & $10616 \pm 3165$ & $1772 \pm 355$ & $0.047 \pm 0.006$ & $0.026 \pm 0.004$ \\
\hline Rim & $43478 \pm 10786$ & $18154 \pm 3489$ & $3361 \pm 928$ & $0.048 \pm 0.001$ & $0.027 \pm 0.001$ \\
\hline Interm & $22384 \pm 4592$ & $8669 \pm 2132$ & $1793 \pm 432$ & $0.112 \pm 0.018$ & $0.049 \pm 0.004$ \\
\hline
\end{tabular}




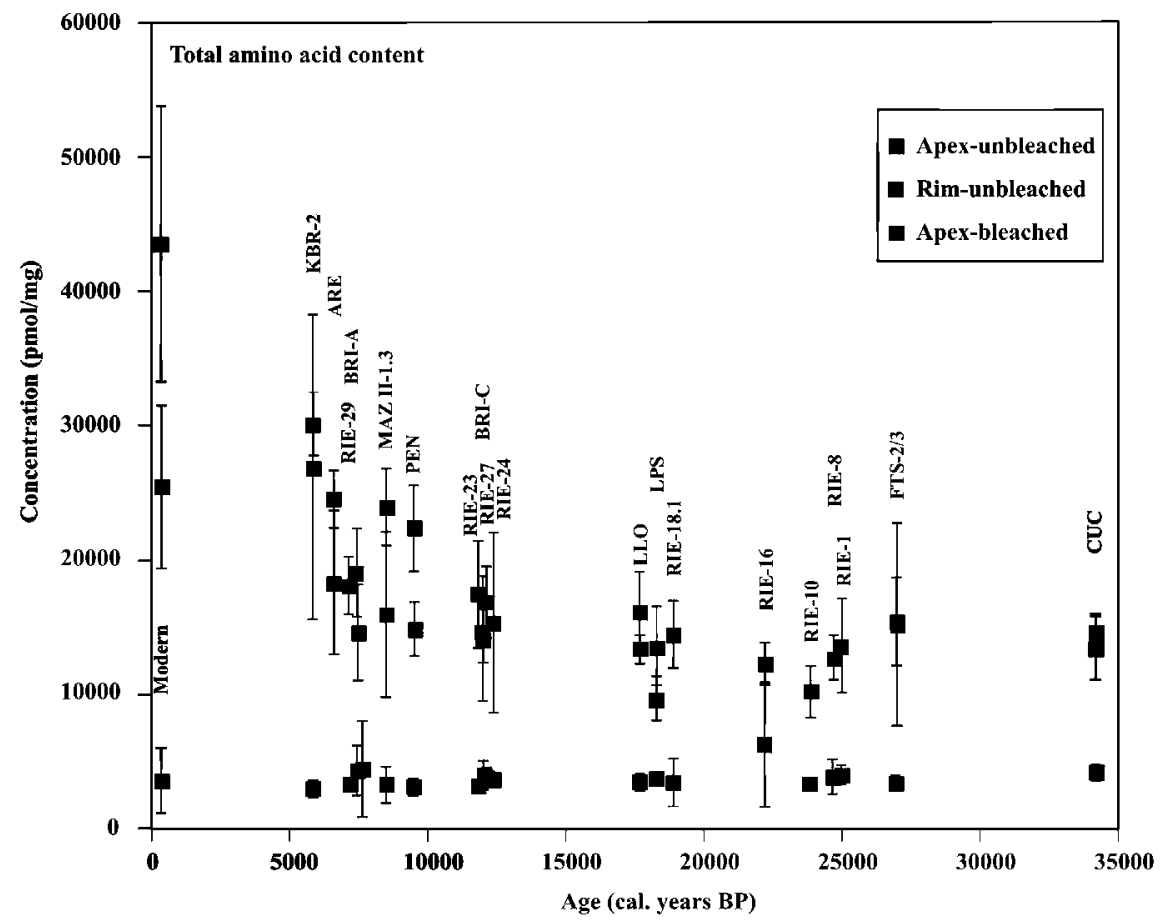

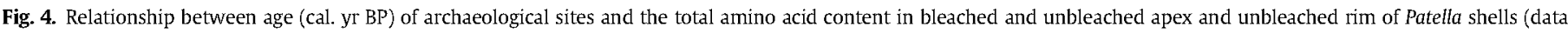
shown in Table 3-Supplementary information).

et al. (2013a) reported slightly higher concentrations of amino acids in the unbleached rim of modern representatives when compared with the unbleached bulk samples (rim + apex). Our findings imply that in spite of sampling different parts of the $P$. vulgata shells (apex, rim), there is no significant intra-shell variation of $D / L$ values from the inter-crystalline fraction.
The total concentration of amino acids present in $P$. vulgata shells was variable within the same archaeological level. This observation has also been made in other molluscs (Penkman et al., 2008; Torres et al., 2013) and can be attributed to diverse factors related to the depositional environment, including taphonomical processes such as chemical dissolution, mechanical fragmentation,

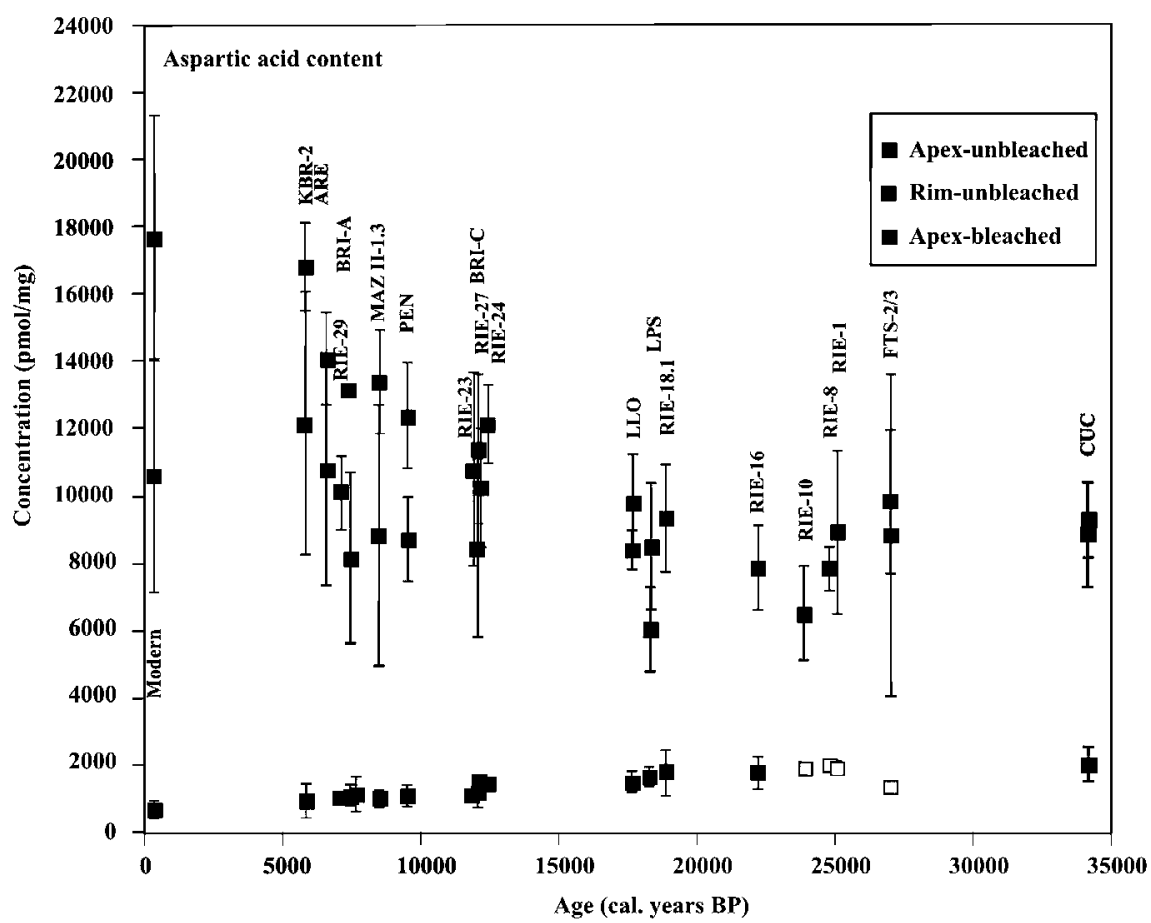

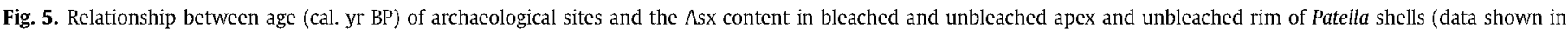
Table 4-Supplementary information). 


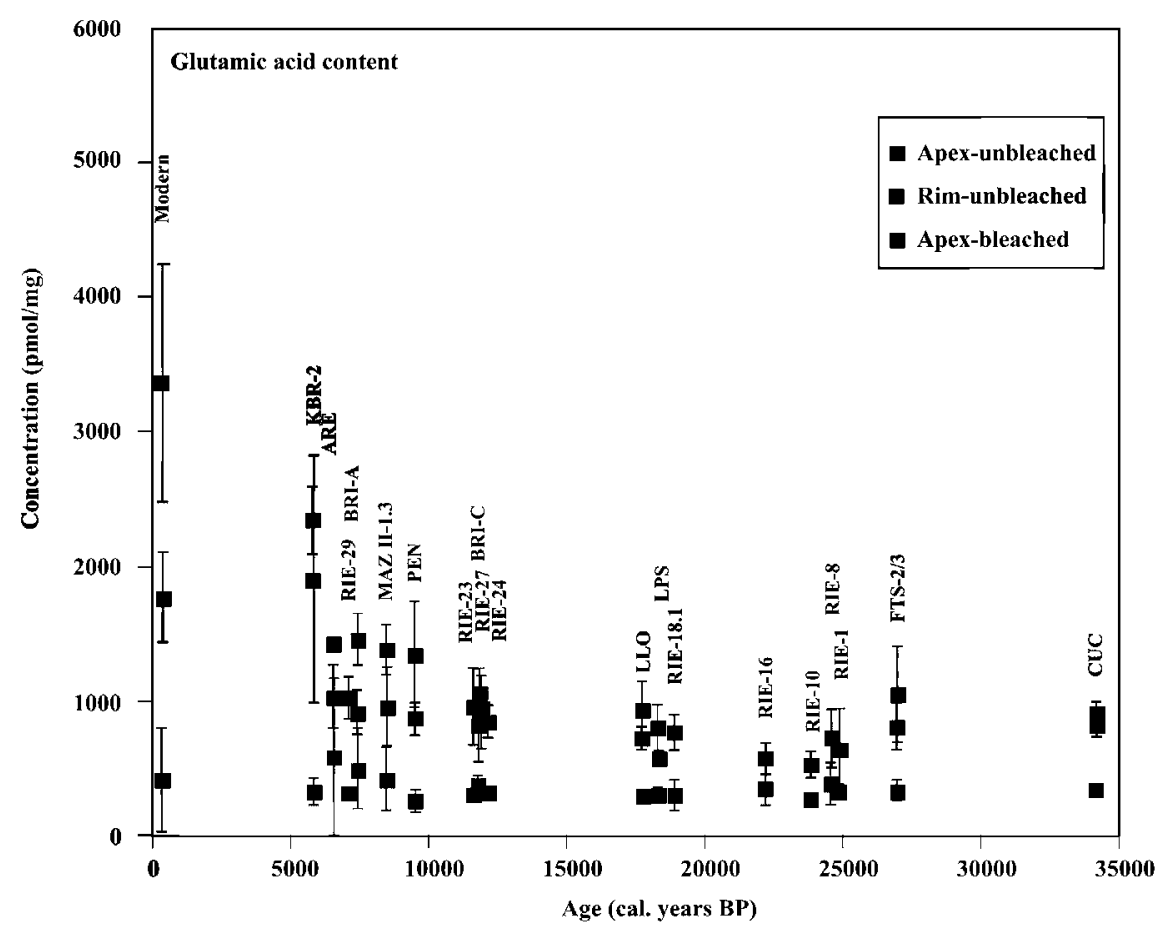

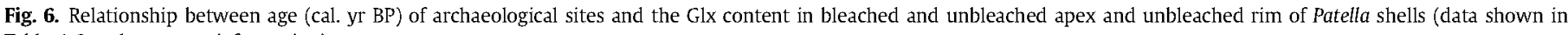
Table 4-Supplementary information).

and bioerosion (Davies et al., 1989; Meldahl et al., 1997; Kidwell, 1998; Carroll et al., 2003; Kidwell et al., 2005), all of which can directly influence the skeletal preservation of shells. Nevertheless, a considerable part of the organic matrix was conserved, thereby reinforcing the notion proposed by Wehmiller (1990) that approximately $30-60 \%$ of the original amino acid concentration remains in carbonate Quaternary fossils.

Asx and Glx D/L values in the aragonitic intermediate part of the modern limpet shells (comprising mostly $\mathrm{M}-1, \mathrm{M}$, and $\mathrm{M}+1$ layers) were higher than in the apex and rim (Table 2 ), which are made of calcite (Fig. 2). Also, the percentages of each amino acid differed slightly, as \%[Ser] and \%[Gly] were lower, whereas \%[Ala], \%[Val] and $\%$ [Leu] were higher than in the apex and rim, thus indicating that other proteins were present, or were represented in differing proportions. These differences were confirmed by the different stain produced in these layers after submerging the shell cross-sections in Mutvei's dye, showing that the calcitic $M-2, M+2$ and $M+3$ layers were richer in organic matter than the aragonitic $M-1$ and M+ 1 layers. According to Marie et al. (2013), Asp-rich proteins, which are more abundant in calcium structures (Sarashina and Endo, 2001; Marin and Luquet, 2004; Gotliv et al., 2005; Marie et al., 2013) are strongly stained with Alcian blue, while other proteins do not show such colouration.

Although differences in the amino acid composition (abundance and percentages) were observed between the aragonitic intermediate part $(M+1, M, M-1)$ and the calcitic apex (M-2) and rim areas $(M+2, M+3)$, there was a high content of acidic amino acids (predominantly Asx) in the whole shell (Fig. 8).

\subsubsection{Intra-crystalline fraction}

The intra-crystalline proteins represented a small fraction with respect to the total proteins in modern Patella shells (ca. 15\%) (Fig. 4) in agreement with Demarchi et al. (2013a), who observed that they represented $10 \%$ in modern shells. Similar to that observed in the inter-crystalline matrix, acidic amino acids were also abundant in the intra-crystalline fraction, representing
$30-35 \%$, vs $45-50 \%$ in the inter-crystalline fraction (Table 3 ). This observation indicates that the inter- and intra-crystalline protein compositions differ, at least in the apex area, thus potentially affecting the AAR rates (Fig. 3). Asx and Glx D/L values were indeed higher in the intra-crystalline fraction of modern limpets.

\section{Protein degradation with age}

\subsection{Amino acid concentrations vs. age}

\subsubsection{Apex and rim - unbleached}

The total amino acid concentration in the apex and rim of unbleached limpet shells (representing the amino acids that comprise inter- and intra-crystalline proteins) was higher in modern specimens than in archaeological ones (Fig. 4); the total amino acid content in the apex decreased by around $40 \%$ from modern to Mesolithic limpets. However, the concentrations were similar in archaeological limpets of diverse ages, even in the oldest samples analysed in this study, with the exception of Les Pedroses cave, in which slightly lower concentrations were detected. Limpets from Kobaederra (Neolithic) showed a large standard deviation, mainly as a result of two samples with amino acid concentrations exceeding $30,000 \mathrm{pmol} / \mathrm{mg}$.

The decrease of the amino acid concentration was especially noticeable in samples taken from the rim area, in which values fell by $~ 30 \%$ in the Neolithic site and $~ 50 \%$ in Mesolithic localities with respect to those of modern specimens. A decrease in the amino acid content in the rim was observed from Mesolithic material to Palaeolithic shells, while this content remained stable in shells from Magdalenian, Solutrean, Gravettian, and Aurignacian sites.

Regarding the concentration of amino acids, [Asx] in the rim and [Glx] in the apex and rim were higher in modern and Neolithic limpets, while they were similar in pre-Neolithic samples (Figs. 4 and 5), although [Asx] content in the apex area did not vary significantly with age.

Similar percentages were obtained for apex and rim sub- 


\section{A-Apex}

Percentage

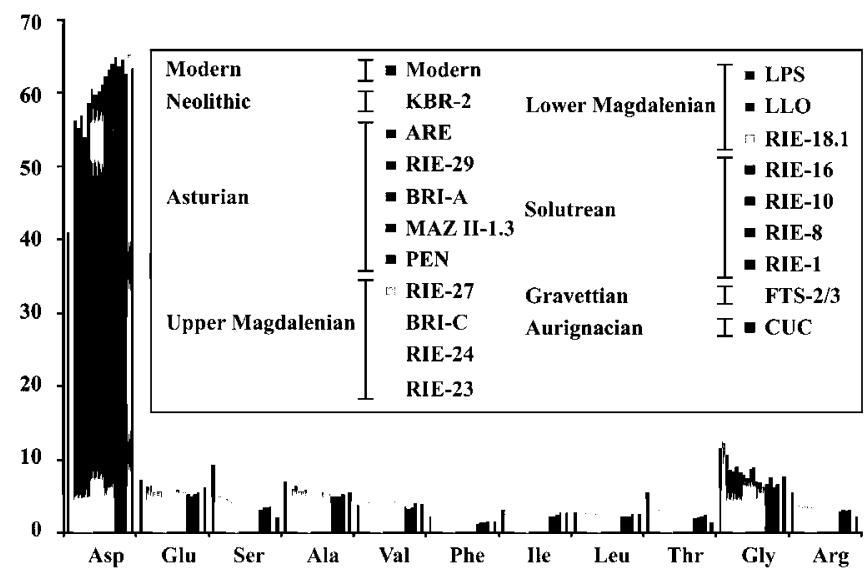

B-Rim

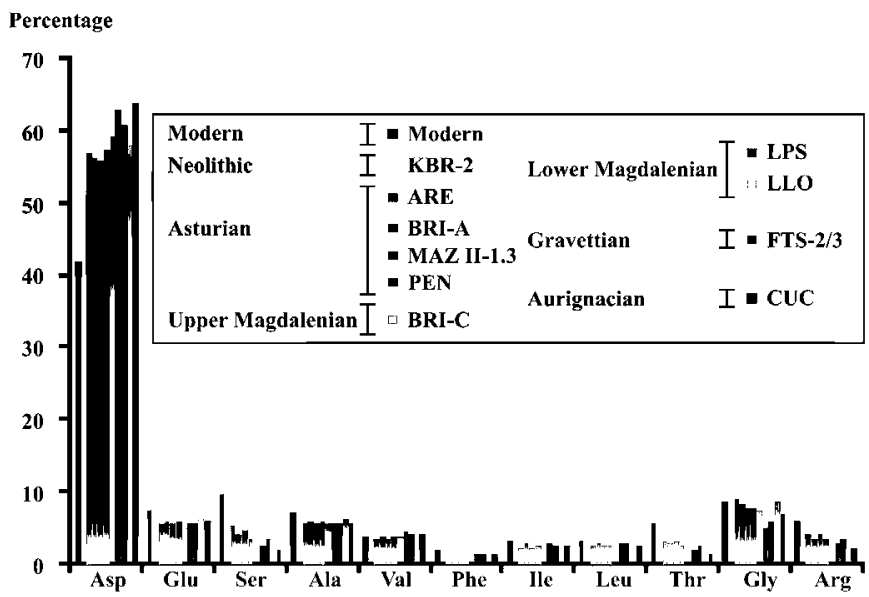

Fig. 7. Percentage of each amino acid in the unbleached apex (A) and rim (B) areas of $P$. vulgata shells from modern and archaeological sites. The same colour code was used for all the levels of the same period, and localities are plotted in age order indicated in the legend. (For interpretation of the references to colour in this figure legend, the reader is referred to the web version of this article.)

samples for all amino acids (considering [Asx], [Glx], [Ser], [lle], [Leu], [Phe], [Val], [Ala], Gly], [Arg] and [Thr]) However, the percentage of each amino acid varied in a different way with age (Fig. 7). The percentage of Asx increased progressively with age (Fig. 7), i.e. for modern specimens it was around $40 \%$, whereas for

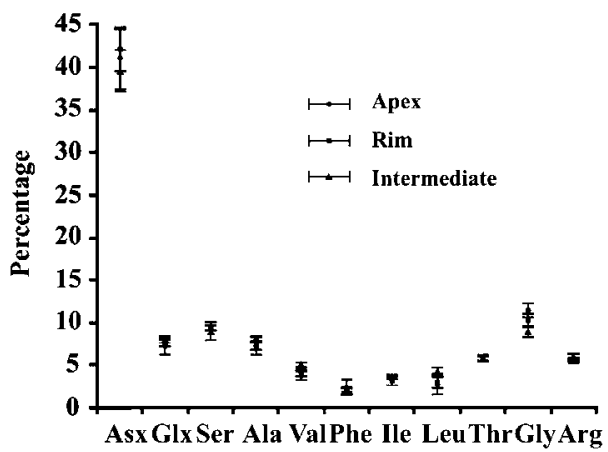

Fig. 8. Percentage of each amino acid concentration in the apex, rim and intermediate areas of modern P. vulgata shells (data shown in Table 5-Supplementary information)
Table 3

Percentage of AsX and Glx content with respect to the total amino acid content of unbleached and bleached samples taken from the apex area of modern and archaeological $P$. vulgata shells in modern and archaeological localities.

\begin{tabular}{llrlllr}
\hline Period & Localities & N & $\begin{array}{l}\text { \%[Asx] } \\
\text { Apex }\end{array}$ & $\begin{array}{l}\text { \%[Asx] } \\
\text { Apex Bleached }\end{array}$ & \multicolumn{1}{l}{$\begin{array}{l}\text { \%[Glx] } \\
\text { Apex }\end{array}$} & \multicolumn{1}{l}{$\begin{array}{l}\text { \%[Glx] } \\
\text { Bleached }\end{array}$} \\
\hline \multirow{4}{*}{$\mathrm{N}$} & Modern & 12 & $41.1 \pm 3.7$ & $23.2 \pm 7.0$ & $7.2 \pm 1.1$ & $10.6 \pm 2.3$ \\
$\mathrm{M}$ & KBR-2 & 4 & $47.1 \pm 5.8$ & $26.0 \pm 12.7$ & $6.9 \pm 1.0$ & $12.8 \pm 3.0$ \\
& RIE-29 & 5 & $56.3 \pm 3.1$ & $27.6 \pm 2.3$ & $5.7 \pm 0.3$ & $9.8 \pm 0.6$ \\
& ARE & 7 & $58.0 \pm 2.7$ & $30.5 \pm 6.7$ & $5.8 \pm 0.6$ & $12.4 \pm 1.9$ \\
& BRI-A & 5 & $52.1 \pm 5.3$ & $29.6 \pm 9.9$ & $7.0 \pm 1.3$ & $12.2 \pm 3.0$ \\
& MAZ Il-1.3 & 9 & $53.2 \pm 7.1$ & $29.8 \pm 6.4$ & $6.4 \pm 1.6$ & $11.8 \pm 1.6$ \\
UM & PEN & 5 & $58.7 \pm 0.9$ & $33.0 \pm 2.7$ & $5.8 \pm 0.1$ & $10.6 \pm 2.9$ \\
& BRI-C & 5 & $59.9 \pm 3.2$ & $32.0 \pm 3.8$ & $5.7 \pm 0.5$ & $9.4 \pm 1.1$ \\
& RIE-27 & 5 & $60.6 \pm 1.9$ & $42.9 \pm 2.4$ & $5.5 \pm 0.4$ & $8.3 \pm 0.4$ \\
& RIE-24 & 3 & $60.4 \pm 0.4$ & $42.0 \pm 5.1$ & $5.4 \pm 0.6$ & $8.9 \pm 1.1$ \\
LM & RIE-23 & 4 & $61.2 \pm 4.6$ & $40.7 \pm 3.3$ & $5.7 \pm 0.9$ & $9.5 \pm 0.5$ \\
& LLO & 5 & $63.4 \pm 2.3$ & $41.0 \pm 4.7$ & $5.4 \pm 0.3$ & $8.1 \pm 0.4$ \\
& LPS & 5 & $62.4 \pm 3.3$ & $44.1 \pm 3.1$ & $6.0 \pm 0.7$ & $8.3 \pm 0.6$ \\
S & RIE-18.1 & 5 & $64.9 \pm 0.3$ & $46.4 \pm 4.6$ & $5.3 \pm 0.3$ & $8.5 \pm 1.0$ \\
& RIE-16 & 5 & $63.8 \pm 3.5$ & $46.5 \pm 2.8$ & $5.1 \pm 0.1$ & $8.4 \pm 0.6$ \\
& RIE-10 & 5 & $64.7 \pm 1.8$ & $45.8 \pm 2.1$ & $5.3 \pm 0.2$ & $8.5 \pm 0.3$ \\
& RIE-8 & 5 & $62.7 \pm 1.4$ & $41.2 \pm 2.5$ & $5.6 \pm 0.3$ & $9.3 \pm 0.5$ \\
& RIE-1 & 5 & $64.1 \pm 3.2$ & $45.1 \pm 2.0$ & $5.5 \pm 0.5$ & $8.3 \pm 0.5$ \\
G & FTS-2/3 & 7 & $64.1 \pm 0.9$ & $40.9 \pm 3.7$ & $5.6 \pm 0.2$ & $9.3 \pm 1.2$ \\
A & CUC & 7 & $66.0 \pm 1.3$ & $49.2 \pm 2.3$ & $5.8 \pm 0.2$ & $8.3 \pm 0.3$ \\
\hline
\end{tabular}

N: Neotlithic; M: Mesolithic (Asturian); UM: Upper Magdalenian; LM: Lower Magdalenian; S: Solutrean; G: Gravettian; A: Aurignacian.

the Neolithic ones (Kobaederra) it was $47 \%$, for Mesolithic ones ca. $55 \%$, and for Magdalenian, Solutrean, Gravettian and Aurignacian ones $65 \%$. In this regard, samples older than ca. 12,500 cal. yr BP (Upper Magdalenian) and up to ca. 34,000 cal. yr BP showed similar proportions of [Asx]. In contrast, the percentages of Glx, Ala, Phe, Gly and Ile showed a sharp decrease in limpets from modern to the Mesolithic age, after which the percentage of these amino acids remained almost constant in Palaeolithic samples.

A rapid decrease was observed in the percentage of [Ser], [Thr], and [Arg] from modern limpets to those of the Mesolithic period, after which the content of these amino acids decreased steadily until ca. $30 \mathrm{ka}$. This was especially significant in [Ser] (from $10 \%$ in modern shells to $2 \%$ in Solutrean ones). It should be noted that the percentages of [Val] and [Leu] remained almost the same.

\subsubsection{Apex - bleached}

The concentration of amino acids in the apex of bleached limpets (representing the amino acids that comprise only intracrystalline proteins) was similar for modern and archaeological representatives of different ages (Fig. 4). The same results were obtained for [Asx] and [Glx] (Figs. 5 and 6).

\subsection{Interpretation of amino acid concentration trends}

\subsubsection{Inter-crystalline amino acids}

Significant protein leaching is likely to have occurred from the inter-crystalline fraction during the ca. $6000 \mathrm{cal}$. yr after the death of the limpets, as the total amino acid content decreased over this time, and then stabilised. After this decrease, the amino acid content in limpets of Mesolithic and Palaeolithic ages (up to ca. 34 cal. ka BP) remained almost the same (Fig. 4), whereas the contribution of each amino acid to the total content differed (Fig. 7). However, [Asx] in the apex area of archaeological shells did not differ significantly with respect to modern ones.

Also, there was an increase in the percentage of $[A s x]$ in both apex and rim areas with age. The percentages of other amino acids such as Glx, Ala, Phe, Gly and Ile decreased with age. This observation might be explained by the position of each amino acid in the 
protein chains, thus producing different degradation rates (Kriausakul and Mitterer, 1980; Mitterer and Kriausakul, 1984; Wehmiller, 1980, 1993).

\subsubsection{Intra-crystalline amino acids}

The intra-crystalline proteins represented around 15\% with respect to the total proteins in modern Patella shells (Fig. 4). This percentage increased with age (up to $20-30 \%$ over $34 \mathrm{ka}$ ), in spite of the apparently limited degradation of the proteins in this fraction (the concentration of amino acids remained constant with age in the bleached samples), indicating that there was a preferential break-down and loss of inter-crystalline proteins. Similarly [Asx] and [Glx] also remained constant with age. This finding coincides with reports by Penkman et al. (2008), who observed that the proportion of intra-crystalline amino acids within the whole shell increases as the sample ages.

of note, acidic amino acids represent a high proportion of the fraction with age, as reflected by the increase in the relative percentages of Asx from modern to Palaeolithic shells (Table 3).

It is also remarkable that while Asx and Glx D/L values differed in the two inter- and intra-crystalline fractions of archaeological limpets, in this case Asx D/L values in intra-crystalline proteins were lower and Glx D/L values were higher than in the inter-crystalline ones (Fig. 3), which could be attributable to the removal of certain proteins and amino acids from the inter-crystalline matrix of the shells when bleaching (cf. Penkman et al., 2007, 2008). In this sense, the higher concentration of free amino acids within the intracrystalline fraction (which are the most highly racemised), may explain the lower Glx D/L values obtained in the inter-crystalline fraction. However, other processes may have to be taken into account, i.e., different amino acids contribute to the proteins entrapped within the biomineral, which undergo racemisation at different rates (cf. Penkman et al., 2008), and the position of each amino acid in the protein chains can produce different degradation rates (Kriausakul and Mitterer, 1980; Mitterer and Kriausakul, 1984; Wehmiller, 1980,1993). As evidence here, the percentage of amino acids differed in bleached and unbleached samples (Table 3). Likewise, partial leaching of the inter-crystalline matrix of proteins may have influenced in the Asx $\mathrm{D} / \mathrm{L}$ values.

The differences found in the concentration and composition of amino acids and $\mathrm{D} / \mathrm{L}$ values between inter- and intra-crystalline proteins are in agreement with Sykes et al. (1995) and Penkman et al. $(2007,2008)$, who observed distinct racemisation rates in these fractions in a variety of mollusc shells. In leaching experiments $\left(140{ }^{\circ} \mathrm{C}\right.$ for $\left.24 \mathrm{~h}-240 \mathrm{~h}\right)$ on unbleached and bleached Bithynia and Patella shells, Penkman et al. (2008) and Demarchi et al. (2013a) observed that only a small percentage (1-4\%) of the total amino acid content leached from the intra-crystalline fraction, in contrast to a higher percentage (ca. 40\%) leached from unbleached shells under the same conditions. While inter-crystalline proteins are more susceptible to decomposition or leaching, the intra-crystalline fraction has been found to approximate a closed system in various mollusc shells. Amino acids within the crystals are apparently effectively isolated from variable external factors, although Orem and Kaufman (2011) observed that the intracrystalline fraction in the bivalve Margaritifera is not a closed system under certain conditions.

\section{Aminochronology of limpet shells}

\subsection{Asx and $G l x D / L$ values vs. age}

\subsubsection{Apex-unbleached}

In general, limpet shells from archaeological sites showed Asx and Glx D/L values consistent with their age (Fig. 3), i.e. in the
Neolithic site (Kobaederra) shells had the lowest Asx and Glx D/L values, followed by those belonging to the Mesolithic (level 29 of La Riera, level 1.3 of Mazaculos II, El Penicial, Bricia-A and Arenillas), Azilian/Magdalenian (level 27 of La Riera), Magdalenian (levels 24, 23 and 18.1 of La Riera, Bricia-C, La Lloseta and Les Pedroses), and Aurignacian (El CuCo) periods. However, some exceptions were detected: in level 2/3 of Fuente del Salin (Gravettian), D/L values were similar to those of the Lower Magdalenian sites. Likewise, Solutrean (levels 16, 10 and 8 of La Riera) and Pre-Solutrean (level 1 from La Riera) sites showed lower Asx D/L values than those expected.

\subsubsection{Apex-bleached}

As with Asx and Glx D/L values of unbleached apex samples, D/ Ls also increased with age in the bleached fraction (Fig. 3). Asx D/L values were higher in the unbleached samples, and a strong correspondence $\left(r^{2}=0.92\right)$ was observed between Asx D/L values of both fractions (Fig. 9). Glx D/L values were slightly higher in bleached Neolithic, Mesolithic, and Upper Palaeolithic shells than those of unbleached samples, being clearly higher in shells from older levels (Fig. 3). Also, a strong correspondence $\left(r^{2}=0.85\right)$ was found between Glx D/L values of both fractions (Fig. 9).

\subsection{Temperature measurement inside the sediment}

Fig. 10 shows a plot of the temperature registered at 4 -h intervals in the sediment of selected archaeological localities in northern Spain over the course of a year (2013), together with atmospheric temperature obtained from the meteorological station of Llanes. The monthly and annual mean temperatures measured in the sediment of selected localities during 2013 are shown in Table 4.

Two main considerations are interpreted from the data recorded: 1) atmospheric temperature affects all localities, although its effect is less marked inside the sediment (10-15 cm deep) at the entrance of the caves (no more than $3 \mathrm{~m}$ far from the entrance), and variations are attenuated; and 2) temperature within the sediment
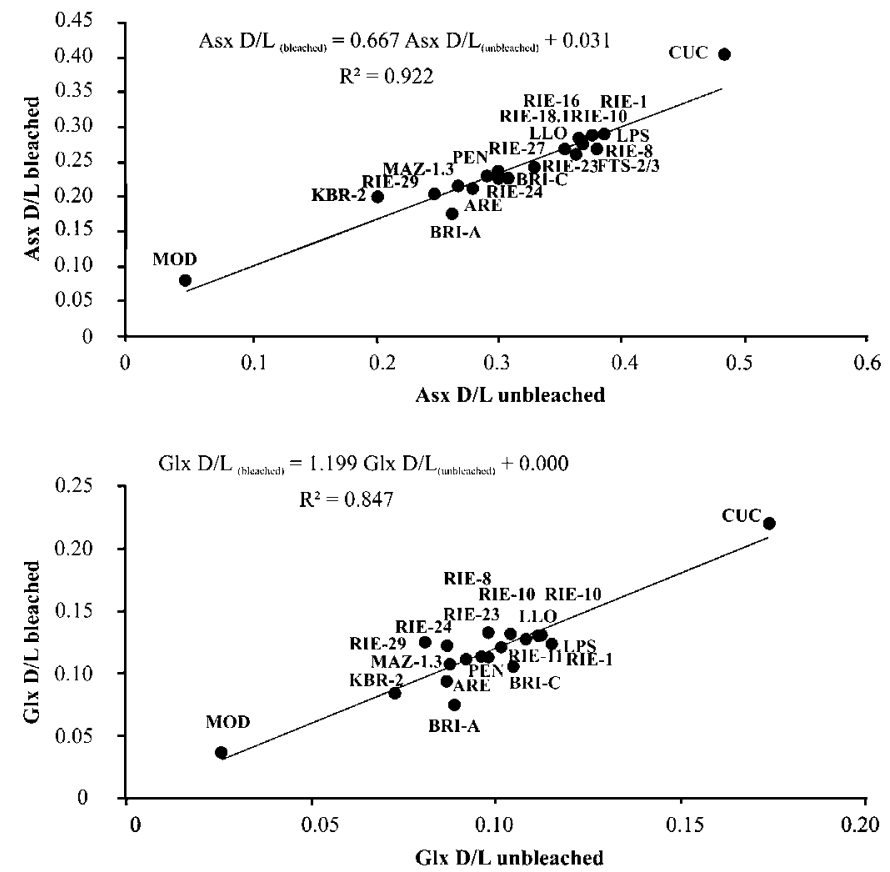

Fig. 9. Comparison of Asx D/L and Glx D/L values in bleached and unbleached samples from the apex of $P$. vulgata shells of different ages. 

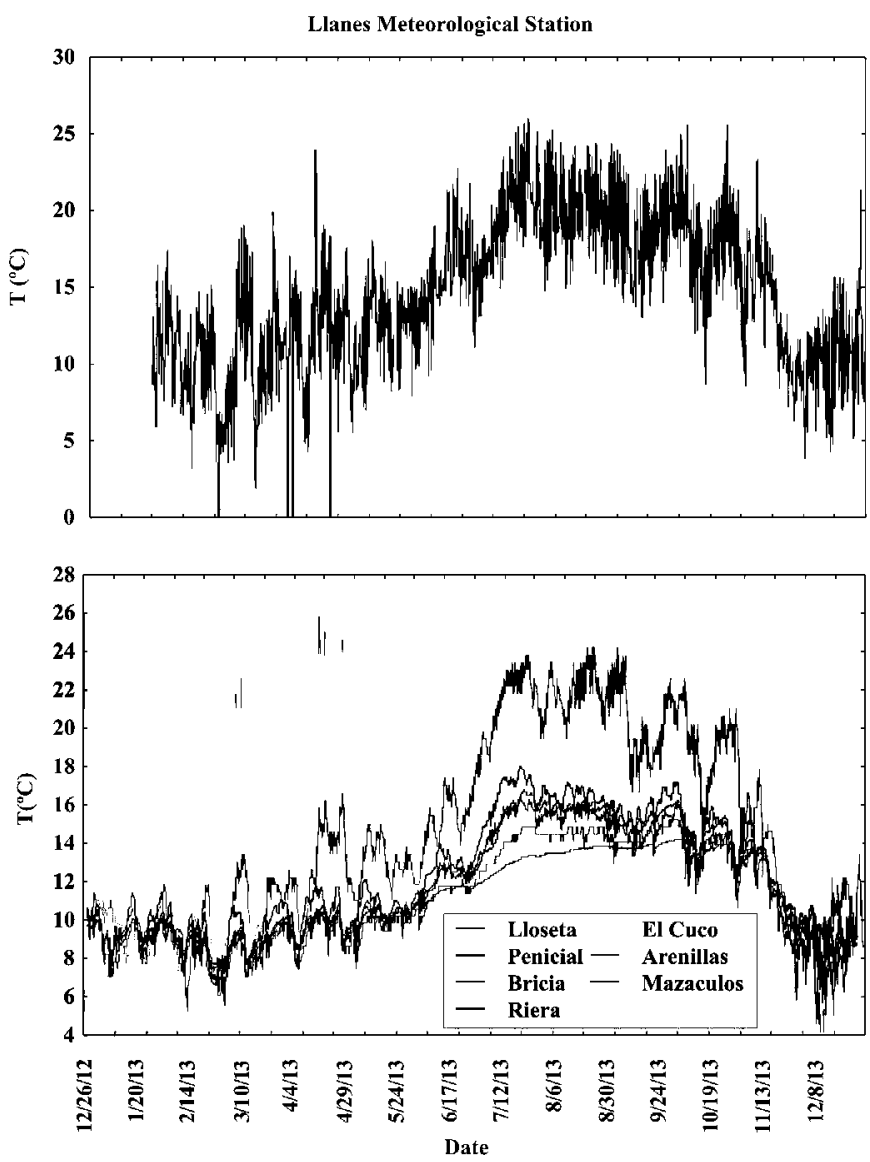

Fig. 10. Annual temperature record of the sediment in some archaeological localities compared to the atmospheric temperature recorded in the meteorological station of Llanes during 2013.

differs between caves. The archaeological remains of Mazaculos II, La Riera, Bricia, El Penicial and La Lloseta are currently preserved at lower temperatures than at other sites, while at El Cuco, temperatures are significantly higher than at the other sites, probably because it is oriented to the south.

\subsection{Aminochronological considerations}

A general increase between Asx D/L values and radiocarbon ages was observed (Fig. 3) up to $18 \mathrm{cal}$. ka. We propose that the palaeoclimatic variations occurred after the accumulation of the archaeological remains affected the amino acid racemization rate of P. vulgata-shells, as it was observed that atmospheric temperature affects sediments bearing the limpets in the entrance of the caves. Levels belonging to the Solutrean (levels $16-1$ of La Riera) and Gravettian (level 2/3 of Fuente Salín) periods showed lower Asx D/L values than expected, but similar values to those typical of Magdalenian localities (Fig. 3). During the Last Glacial Maximum (LGM), temperatures in the sediment would have been lower than during the Holocene, i.e., according to Bard (2002) and Peck et al. (2008), sea surface temperature in the North Atlantic during the LGM was $5-6^{\circ} \mathrm{C}$ lower than during the Holocene, thus decreasing the racemisation rate. This is especially noticeable at La Riera, where Asx D/L values of shells in the Asturian, Azilian/Magdalenian, Magdalenian levels were in agreement with calibrated ${ }^{14} \mathrm{C}$ ages and the periods to which they belong (Fig. 3). In contrast, limpets in the Solutrean and Pre-Solutrean levels showed lower Asx D/L values than expected (Fig. 3), and probably those of Lower Magdalenian as well. As we observed, the main leaching of open-system proteins occurred during the first $6000 \mathrm{yr}$ after the death of the limpets (Fig. 4). As temperature influences the racemisation rates of amino acids, the low temperatures that occurred during the Last Glaciation appears to have slowed the racemisation of limpets from 27,000 cal. yr BP to at least 18,000 cal. yr BP, after which they followed a similar rate to that of shells in Magdalenian levels (18,000-12,000 cal. yr BP). This explanation could account for the observation that limpets from the Solutrean and Gravettian levels showed lower Asx D/L values than those expected, with an apparent decrease in racemisation between 18 and $27 \mathrm{cal}$ ka BP i.e, both in unbleached and bleached apex of limpets (Fig. 3).

It is noticeable that the El Cuco samples, deposited under cold conditions, showed significantly higher Asx and Glx D/L values than levels belonging to Solutrean and Gravettian. This may be explained by the orientation of the entrance of this site (to the south), increasing the solar radiation received in comparison with other localities. In support of this, higher temperatures were measured by the loggers (Table 4, Fig. 10), indicating that this site may have not been as affected by the decrease in rates due to cold conditions as the other sites. Nevertheless, other explanations are possible, including that the ${ }^{14} \mathrm{C}$ ages for the El Cuco remains may be in error; it is planned to perform new radiometric dating.

The climate amelioration that occurred from the start of the Late-Glacial and throughout the Holocene explains the general agreement between radiocarbon ages and the aminostratigraphy of Magdalenian, Azilian, Mesolithic and Neolithic levels. However, in some cases there was a discordance, which may be explained by the taphonomical conditions that affected these sites.

Of note, level A of Bricia Cave and the shell midden of La Riera (level 29) were dated by ${ }^{14} \mathrm{C}$ at $7375 \pm 185 \mathrm{cal}$. yr BP and $7680 \pm 150$ cal. yr BP (Clark, 1976), respectively, but they showed different mean Asx D/L values $(0.264 \pm 0.008$ for level A of Bricia, and $0.248 \pm 0.009$ for La Riera shell midden-level 29). Although these two caves are less than $100 \mathrm{~m}$ apart and positioned on the same karstic massif, they also showed different mean annual temperatures over the year recorded. La Riera Cave experienced lower temperatures, especially noticeable during the summer months, in which a mean difference of $3^{\circ} \mathrm{C}$ was observed, whereas during winter, temperatures differed by less than $1{ }^{\circ} \mathrm{C}$. Glx D/L values were only slightly higher in BRI-A $(0.089 \pm 0.004)$ than in

Table 4

Mean monthly and annual temperature (in degrees Celsius) record in the sediment of some archaeological localities (measured at 4-h intervals).

\begin{tabular}{|c|c|c|c|c|c|c|c|c|c|c|c|c|c|}
\hline Cave & Annual & January & February & March & April & May & June & July & August & September & October & November & December \\
\hline Cuco & 17.6 & 14.2 & 13.4 & 15.5 & 17.2 & 15.7 & 16.8 & 20.8 & 22.5 & 22.3 & 21.1 & 16.3 & 14.6 \\
\hline Arenillas & 15.2 & 10.4 & 9.6 & 11.5 & 13.5 & 13.6 & 16.2 & 21.8 & 22.3 & 20.4 & 19.0 & 13.2 & 10.9 \\
\hline Mazaculos & 11.8 & 9.0 & 8.6 & 8.6 & 9.6 & 10.3 & 12.3 & 15.3 & 15.6 & 14.9 & 14.2 & 11.8 & 8.6 \\
\hline La Riera & 11.2 & 9.6 & 9.1 & 9.0 & 9.7 & 10.2 & 11.4 & 12.8 & 13.6 & 13.8 & 13.6 & 12.0 & 9.3 \\
\hline Bricia & 12.2 & 9.5 & 9.0 & 9.4 & 10.3 & 10.7 & 12.7 & 16.5 & 16.5 & 15.7 & 14.8 & 12.0 & 9.2 \\
\hline Penicial & 11.8 & 9.2 & 8.8 & 8.8 & 9.9 & 10.3 & 12.1 & 15.3 & 15.9 & 15.3 & 14.6 & 12.3 & 9.0 \\
\hline Lloseta & 11.0 & 8.9 & 8.7 & 8.5 & 9.3 & 9.6 & 11.4 & 13.9 & 14.5 & 14.2 & 13.8 & 11.4 & 7.8 \\
\hline
\end{tabular}


RIE-29 $(0.081 \pm 0.005)$, which is explained by the lower racemisation rate of Glx in comparison with that of Asx.

Likewise, the mean Asx D/L value in Arenillas rock-shelter was higher than expected, as the shell midden remains were dated at $6385 \pm 70$ cal. yr BP (Bohígas and Muñoz Fernández, 2002). In this case, the mean annual temperature was observed to be higher $\left(3-4{ }^{\circ} \mathrm{C}\right.$ ) than in other localities of similar age (Fig. 10), explaining the Asx $\mathrm{D} / \mathrm{L}$ values. In addition, recent radiocarbon dating has indicated that these deposits accumulated ca. 7800 cal. yr BP (unpublished data). However, the effects of other factors in elevating the $\mathrm{D} /$ Ls cannot be ruled out.

This study indicates that Asx D/L and Glx D/L provide a useful method for dating limpets from archaeological levels younger than ca. $18 \mathrm{cal}$. ka BP in this region. For older sites (at least those belonging to the Gravettian and Solutrean which were formed under cold climates), past temperatures are likely to have decreased racemisation rates, and extrapolation of Asx D/L values to age should therefore take this into account. Likewise, taphonomical and environmental conditions must be considered in all sites for accurate age estimation.

\section{Conclusions}

In summary:

1. Amino acid $\mathrm{D} / \mathrm{L}$ values in the apex $(\mathrm{M}+3$ and $\mathrm{M}+2$ layers $)$ and rim (M -2 layer) areas of unbleached $P$. vulgata shells are comparable and can therefore both be used for the age calculation of archaeological localities. These zones are made of the same polymorph of calcium carbonate (calcite). In contrast, $\mathrm{D} / \mathrm{L}$ values in the aragonitic intermediate area $(M+1, M$ and $M-1$ layers) are higher.

2. Proteins in rim and apex areas are probably similar, as the percentages of amino acids within them contribute the same percentage to the total amino acid content and vary in the same way with increasing age. Nevertheless, higher amounts of amino acids were found in the rim of modern limpet shells than in the apex, although in archaeological ones, similar concentrations were observed.

3. The main leaching of open-system proteins in $P$. vulgata shells (at least the inter-crystalline fraction) occurred within the first $6000 \mathrm{cal}$. yr BP after the death of the organism. This is evidenced by the considerable decrease in the total amino acid content in Mesolithic samples with respect to modern and Neolithic ones. However, leaching may be faster, as limpets from the Neolithic Kobaederra- 2 site showed high variability in the concentrations and percentages of amino acids with respect to those of modern ones. However, the total amount of amino acids in the intracrystalline fraction remained virtually intact for at least $34 \mathrm{ka}$.

4. [Asx] remained constant with age (over ca. $34 \mathrm{cal}$ ka BP), both in inter- and intra-crystalline proteins. While the contribution of [Asx] to the total amino acid content was higher in the former, in both fractions it increased with age. The percentage of Asx increased with age in unbleached shells: from $42 \%$ in modern limpets to $47 \%$ in Neolithic, $55 \%$ in Mesolithic, and $65 \%$ in Magdalenian, Solutrean, Gravettiean and Aurignacian representatives. The contribution of Asx to the total amino acid content in bleached shells also increased with age (over ca. 34 cal ka BP), although percentages varied. In contrast, the concentration of other amino acids decreased with age ([Glx], [Ser], [Ala], [Phe], [lle], [Gly], [Thr] and [Arg]), whereas the percentage of [Val] and [Leu] remained almost constant.

5. Differences in amino acids that contribute to the inter- and intra-crystalline proteins, which undergo racemisation at different rates, may be produced because the products of diagenesis are likely to remain in the intra-crystalline fraction. Likewise, the preferential removal of certain proteins and amino acids from the inter-crystalline matrix through time, might produce that the inter-crystalline protein fraction degraded faster than the intra-crystalline one. Although Asx D/L values were higher in unbleached samples, there was good correspondence between Asx $\mathrm{D} / \mathrm{L}$ values in inter- and intracrystalline proteins. However, other amino acids, such as Glx, showed lower levels of racemisation in the inter-crystalline proteins, at least in the first ca. 12,000 cal yr. In our view, it is sufficient to analyse unbleached samples to establish the age of archaeological levels, but bleaching provides important information and complements the interpretation obtained from the inter-crystalline fraction.

6. Atmospheric temperature affects the sediment bearing the archaeological remains and thus contributes to the rate of AAR of $P$. vulgata, thus explaining why the Gravettian and Solutrean localities, formed during cold conditions, showed $\mathrm{D} / \mathrm{L}$ values similar to those of Magdalenian ones.

\section{Acknowledgements}

This paper was made possible by funding from the Spanish Ministry of Science and Innovation projects: HAR2010-22115-C0201 "La respuesta humana al cambio climático global en una zona litoral: el caso del tránsito al Holoceno en la costa cantábrica (10000-5000 cal BC)", and HAR2010-22115-C02-02 "Aplicación del análisis de sustancias orgánicas e inorgánicas a la reconstrucción paleoambiental, cronológica y tafonómica de yacimientos arqueológicos del Norte de España". We would like to thank the Museo de Prehistoria y Arqueología de Cantabria, Museo y Centro de Investigación de Altamira, Museo de Prehistoria de Asturias for facilitating the access to the archaeological material. We also thank the "Agencia Estatal de Meteorologia" of Spain for facilitating the hourly temperatures of selected meteorological stations from Northern Spain. We thank Kirsty Penkman and an anonymous reviewer for their valuable and helpful comments on the manuscript.

\section{Appendix A. Supplementary data}

Supplementary data related to this article can be found at http:// dx.doi.org/10.1016/j.quageo.2015.02.008.

\section{References}

Álvarez-Fernández, E., 2011. Humans and marine resource interaction reappraised archaeofauna remains during the late Pleistocene and Holocene in Cantabrian Spain. J. Anthropol. Archaeol. 30, 327-343.

Bailey, G.N., Craighead, A.S., 2003. Late Pleistocene and Holocene coastal paleoeconomies: a reconsideration of the molluscan evidence from Northern Spain Geoarchaeology Int. J. 18 (2), 175-204.

Bard, E., 2002. Climate shock: abrupt changes over millenial time scales. Phys. Today 55, 32-38.

Bateman, M.D., Carr, A.S., Murray-Wallace, C.V., Roberts, D.L., Holmes, P.J., 2008. A dating intercomparison study on Late Stone Age coastal midden deposits, South Africa. Geoarchaeology 23, 715-741.

Bohígas, R., Muñoz Fernández, E., 2002. Excavaciones arqueológicas de urgencia en el Covacho de Arenillas (Isalares, Castro Urdiales) 1992. In: Ontañón, R. (Ed.), Actuaciones Arqueológicas en Cantabria 1987-1999. Arqueología de Gestión, Gobierno de Cantabria, Santander, pp. 45-47.

Carroll, M., Kowalewski, M., Simōes, M.G., Goodfriend, G.A., 2003. Quantitative estimates of time-averaging in terebratulid brachiopod shell accumulations from a modern tropical shelf. Paleobiology 29, 381-402.

Clark, G.A., 1976. El Asturiense Cantábrico. In: Bibliotheca Prehistórica Hispana XIII, Madrid.

Cohen, A.L., Branch, G.M., 1992. Environmentally controlled variation in the structure and mineralogy of Patella granularis shells from the coast of southern Africa: implications for palaeotemperature assessments. Palaeogeogr. Palaeoclimatol. Palaeoecol. 91, 49-57.

Davies, D.J., Powell, E.N., Stanton, R.J., 1989. Relative rates of shell dissolution and 
net sediment accumulation - a commentary: can shell beds form by the gradual accumulation of biogenic debris on the sea floor? Lethaia 27, 207-212.

Demarchi, B., Williams, M.G., Milner, N., Russell, N., Bailey, G.N., Penkman, K.E.H., 2011. Amino acid racemization dating of marine shells: a mound of possibilities. Quat. Int. 239 (1-2), 114-124.

Demarchi, B., Rogers, K., Fa, D.A., Finlayson, C.J., Milner, N., Penkman, K.E.H., 2013a. Intra-crystalline protein diagenesis (ICPD) in Patella vulgata. Part I: isolation and testing of the closed system. Quat. Geochronol. 16, 144-157.

Demarchi, B., Collins, M.J., Tomiak, P.J., Davies, B.J., Penkman, K.E.H., 2013b. Intracrystalline protein diagenesis (ICPD) in Patella vulgata. Part II: breakdown and temperature sensitivity. Quat. Geochronol. 158-172.

Fenger, T., Surge, D., Schöne, B., Milner, N., 2007. Schlerochronology and geochemical variation in limpet shells (Patella vulgata): a new archive to reconstruct coastal sea surface temperature. Geochem. Geophys. Geosyst. 8 (7), Q07001. http://dx.doi.org/10.1029/2006GC001488.

Forli, M., Dell'Angelo, B., Montagna, P., Taviani, M., 2004. A new large Patella (Mollusca: Archaeogastropoda) in the Pliocene of the Mediterranean Basin. Boll. Malacol 40, 1-9

Glover, E., Glover, I., Vita-Finzi, C., 1990. First-order 14C dating of marine molluscs in archaeology. Antiquity $64,562-567$.

González-Morales, M.R., 1982. El Asturiense Y Otras Culturas Locales. In: Monografías del Centro de Investigación y Museo de Altamira, Santander

Gotliv, B.A., Kessler, N., Sumerel, J.L., Morse, D.E., Tuross, N., Addadi, L., Weiner, S, 2005. Asprich: a novel aspartic acid-rich protein family from the prismatic shel matrix of the bivalve Atrina rigida. ChemBioChem 6, 304-314.

Gutiérrez Zugasti, F.I., 2009. La explotación de moluscos y otros recursos litorales en la región cantábrica durante el Pleistoceno final y el Holoceno inicial. PUblican, Ediciones de la Universidad de Cantabria, Santander.

Gutiérrez Zugasti, F.I., 2011. Coastal resource intensification across the PleistoceneHolocene transition in Northern Spain: evidence from shell size and age distributions of marine gastropods. Quat. Int. 244, 54-66.

Haugen, J.E., Sejrup, H.P., 1992. Isoleucine epimerization kinetics in the shells of Arctica islandica. Nor. Geol. Tidsskr. 72, 171-180.

Hearty, P.J., ÓLeary, M.J., Kaufman, D.S., Page, M.C., Bright, J., 2004. Amino acid geochronology of individual foraminifer (Pulleniatina obliquiloculata) tests north Queenland margin, Australia: a new approach to correlating and dating Quaternary tropical marine sediment cores. Paleoceanography 19, PA4022. http://dx.doi.org/10.1029/2004PA001059.

Hernández-Pacheco, F., Llopis-Lladó, N., Jordá-Cerdá, F., Martínez, J.A., 1957. Libro Guía de la Excursión N2. El Cuaternario de la Región Cantábrica 28-29. Diputación Provincial de Asturias, Oviedo.

Jordá, F., 1954. La cueva de Bricia (Asturias). Bol. Inst. Estud. Astur. XXII, 169-195.

Jordá, F., 1957. Prehistoria de la Región Cantábrica. In: Diputación Provincial de Asturias, Servicio de Investigaciones Arqueológicas, Oviedo.

Jordá, F., 1958. Avance al estudio de La Lloseta (Ardines, Ribadesella, Asturias). In: Memorias del Servicio de Investigaciones Arqueológicas de Asturias, vol. 3 (Oviedo).

Kaufman, D.S., 2000. Amino acid racemization in ostracodes. In: Goodfriend, G., Collins, M., Fogel, M., Macko, S., Wehmiller, J. (Eds.), Perspectives in Amino Acid and Protein Geochemistry. Oxford University Press, New York, pp. 145-160.

Kaufman, D.S., 2003. Amino acid paleothermometry of Quaternary ostracodes from the Bonneville Basin. Utah. Quat. Sci. Rev. 22, 899-914.

Kaufman, D.S., 2006. Temperature sensitivity of aspartic and glutamic acid race mization in the foraminifera Pulleniatina. Quat. Geochronol 1, 188-207.

Kaufman, D.S., Manley, W.F., 1998. A new procedure for determining DL amino acid ratios in fossils using reverse phase liquid chromatography. Quat. Geochronol. $17,987-1000$.

Kidwell, S.M., 1998. Time-averaging in the marine fossils record: overview of strategies and uncertainties. Geobios 30 (7), 977-995.

Kidwell, S.M., Best, M.M.R., Kaufman, D.S., 2005. Taphonomic trade-offs in tropical marine death assemblages: differential time-averaging, shell loss, and probable bias in siliciclastic vs. carbonate facies. Geology 33, 729-732.

Kosnik, M.A., Kaufman, D.S., 2008. Identifying outliers and assessing the accuracy of amino acid racemization measurements for geochronology: II. Data screening. Quat. Geochronol. 3, 328-341.

Kriausakul, N., Mitterer, R.M., 1980. Some factors affecting the epimerization of isoleucine in peptides and proteins. In: Hare, P.E., Hoering, T.C., King Jr., J. (Eds.) Biogeochemistry of Amino Acids. Wiley, New York, pp. 283-296.

Laabs, B.J., Kaufman, D.S., 2003. Quaternary highstands in Bear Lake valley, Utah and Idaho. Geol. Soc. Am. Bullet 115, 463-478.

MacClintock, C., 1967. Shell Structure of Patelloid and Bellerophontoid Gastropods (Mollusca) Peabody Museum of Natural History, Yale University, New Haven.

Marie, B., Jackson, D.J., Ramos-Silva, P., Zanella-Cléon, I., Guichard, N., Marin, F. 2013. The shell-forming proteome of Lottia gigantea reveals both deep conservations and lineage-specific novelties. FEBS J. 280, 214-232.

Marin, F., Luquet, G., 2004. Molluscan shell proteins. C.R. Palevol 3, 469-492.

Marin, F., Leroy, N., Silva, P., Marie, B., 2012. The formation and mineralization of mollusc shell. Front. Biosci. 4, 1099-1125.

Masters, P. Bada, J.L., 1977. Racemization of isoleucine in fossil molluscs from Indian middens and interglacial terraces in southern California. Earth Planet. Sci. Lett. $37,173-183$

Meldahl, K.H., Flessa, K.W., Cutler, A.H., 1997. Time-averaging and postmortem skeletal survival in benthic fossil assemblages: quantitative comparisons among Holocene environments. Paleobiology 23, 209-229.

Mitterer, R.M., Kriausakul, N., 1984. Comparison of rates and degrees of isoleucine epimerization in dipeptides and tripeptides. Org. Geochem. 7, 91-98.

Moure, A., González Morales, M.R., 1992. Datation 14C d'une zone décorée de la grotte Fuente del Salín en Espagne, vol. 3. INORA, pp. 1-2.

Muñoz Fernández, E., Rasines Del Río, P., Santamaría Santamaría, S., Morlote Expósito, J.M., 2007. Estudio arqueológico del abrigo del Cuco. In: Muñoz Fernández, E., Montes Barquín, R. (Eds.), Intervenciones arqueológicas en Castro Urdiales, Arqueología y arte rupestre paleolítico en las cavidades de El Cuco o Sobera y La Lastrilla. Excmo. Ayuntamiento de Castro Urdiales, tomo III. Concejalía de Medio Ambiente y Patrimonio Arqueológico, Castro Urdiales (Spain), pp. 15-160.

Murray-Wallace, C.V., 1995. Aminostratigraphy of Quaternary coastal sequences in southern Australia an overview. Quat. Int. 26, 69-86.

Murray-Wallace, C.V., Goede, A., 1995. Aminostratigraphy and electron spin resonance dating of Quatemary coastal neotectonism in Tasmania and the Bass Strait islands. Aust. J. Earth Sci. 42, 51-67.

Mutvei, H., Westermark, T., Duncan, E., Carell, B., Forsberg, S., Bignert, A., 1994 Methods for the study of environmental changes using the structural and chemical information in molluscan shells. Past and present biomineralization processes, considerations about the carbonate cycle. Bull. Mus. Oceanogr. Monaco 163-919. Special number 13.

Orem, C., Kaufman, D.S., 2011. Effects of basic $\mathrm{pH}$ on amino acid racemization and leaching in freshwater mollusk shell. Quat. Geochronol. 6, 233-245.

Ortiz, J.E., Torres, T., González-Morales, M.R., Abad, J., Arribas, I., Fortea, F.J., GarcíaBelenguer, F., Gutiérrez-Zugasti, I., 2009a. The aminochronology of maninduced shell middens in caves in Northern Spain. Archaeometry 51, 123-139.

Ortiz, J.E., Torres, T., Delgado, A., Reyes, E., Díaz-Bautista, A., 2009b. A review of the Tagus river tufa deposits (central Spain): age and palaeoenvironmental record. Quat. Sci. Rev. 28, 947-963.

Peck, V.L., Hall, I.R., Zahn, R., Elderfield, H., 2008. Millennial-scale surface and subsurface paleothermometry from the northeast Atlantic, 55-8 ka BP. Paleoceanography 23, PA3221. http://dx.doi.org/10.1029/2008PA001631.

Penkman, K.E.H., Preece, R.C., Keen, D.H., Maddy, D., Schreve, D.S., Collins, M.J., 2007. Testing the aminostratigraphy of fluvial archives: the evidence from intracrystalline proteins within freshwater shells. Quat. Sci. Rev. 26, 2958-2969.

Penkman, K.E.H., Kaufman, D.S., Maddy, D., Collins, M.J., 2008. Closed-system behaviour of the intra-crystalline fraction of amino acids in mollusk shells. Ouat. Geochronol. 3, 2-25.

Reimer, P.J., Bard, E., Bayliss, A., Beck, J.W., Blackwell, P.G., Bronk Ramsey, C. Buck, C.E., Cheng, H., Edwards, R.L., Friedrich, M., Grootes, P.M., Guilderson, T.P., Haflidason, H., Hajdas, I., Hatté, C., Heaton, T.J., Hogg, A.G., Hughen, K.A., Kaiser, K.F., Kromer, B., Manning, S.W., Niu, M., Reimer, R.W., Richards, D.A. Scott, E.M., Southon, J.R., Turney, C.S.M., van der Plicht, J., 2013. IntCal13 and MARINE13 radiocarbon age calibration curves $0-50000$ years calBP. Radiocarbon 55 (4). http://dx.doi.org/10.2458/azu js_rc.55.16947.

Sarashina, I., Endo, K., 2001. The complete primary structure of Molluscan Shell Protein 1 (MSP-1), an acidic glycoprotein in the shell matrix of the scallop Patinopecten yessoensis,. Mar. Biotechnol. 3, 362-369.

Schöne, B.R., Dunca, E., Fiebig, J., Pfeiffer, M., 2005. Mutvei's solution: an ideal agent for revolving microgrowth structures of biogenic carbonates. Palaeogeogr. Palaeoclimatol. Palaeoecol. 228, 149-166.

Stein, J.K., Deo, J.N., 2003. Big sites-short time. Accumulation rates in archaeological sites. J. Archaeol. Sci. 30, 297-316.

Straus, L.G., Clark, G.A., 1986. La Rieva Cave. Stone Age Hunter-Gatherer Adaptations in Northern Spain. Arizona. In: Anthropological Research Papers, vol. 36. Arizona State University.

Straus, L.G., Bernaldo de Quirós, F., Cabrera, V., Clark, G.A., 1978. Solutrean chronology \& Lithic variability in Vasco-Cantabrian Spain. Zephyrus 28-29, 109-113.

Stuiver, M., Reimer, P.J., Reimer, R.W., 2014. CALIB 7.0. (program and documentation). http://calib.qub.ac.uk/calib/ (accessed 10.09.14.).

Sykes, G.A., Collins, M.J., Walton, D.I., 1995. The significance of a geochemically isolated intracrystalline fraction within biominerals. Org. Geochem. 23, 1059-1065.

Torres, T., Llamas, J., Canoira, L., García-Alonso, P., Garcia-Cortés, A., Mansilla, H. 1997. Amino acid chronology of the lower Pleistocene deposits of Venta Micena (Orce, Granada, Andalusia, Spain). Org. Geochem. 26, 85-97.

Torres, T., Llamas, J.F., Canoira, L., García Alonso, P., Coello, F.J., 1999. Variaciones intraconcha e interconcha de la racemización del ácido aspártico en moluscos holocenos del Golfo de Cádiz (SO de España). Geogaceta 26, 111-114.

Torres, T., Ortiz, J.E., Arribas, I., 2013. Variations in racemization/epimerization ratios and amino acid content of Glycymeris shells in raised marine deposits in the Mediterranean realm. Quat. Geochronol. 16, 35-49.

Vega del Sella, C., 1914. La Cueva del Penicial (Asturias), vol. 4. Comisión de Investigaciones Paleontológicas y Prehistóricas, Madrid.

Watabe, M., 1984. Shell. In: Bereiter-Hahn, J., Matolsy, A.G., Richards, K.S. (Eds.), The Biology of the Integument 1. Invertebrates. Springer, Berlin, pp. 448-485.

Wehmiller, J.F., 1977. Amino acid studies of the Del Mar, California, midden siteApparent rate constants, ground temperature models, and chronological implications. Earth Planet. Sci. Lett. 37, 184-196.

Wehmiller, J.F., 1980. Intergeneric differences in apparent racemization kinetics in mollusks and foraminifera: implications for models of diagenetic racemization. In: Hare, P.E., Hoering, T.C., King Jr., K. (Eds.), Biogeochemistry of Amino Acids. John Willey and Sons, New York, pp. 341-355.

Wehmiller, J.F., 1984. Interlaboratory comparison of amino acid enantiomeric ratios in fossil mollusks. Quat. Res. 22, 109-120. 
Wehmiller, J., 1990. Amino acid racemization: application in chemical taxonomy and chronostratigraphy of Quaternary fossils. In: Carter, J.G. (Ed.), Skeletal Biomineralization: Patterns, Processes and Evolutionary Trends. Van Nostrand Reinhold, New York, pp. 583-607.

Wehmiller, J.F., 1993. Applications of organic geochemistry for Quaternary research In: Engel, M.H., Macko, S.A. (Eds.), Organic Geochemistry. Plenum Press, New York, pp. $755-783$.
Wehmiller, J.F., Miller, G., De Vogel, S., Kaufman, D.S., Bright, J., Murray-Wallace, C.V. Ortiz, J.E., Penkman, K., 2010. Interlaboratory comparison of amino acid D/L values. In: Geological Society of America Annual Meeting, Denver, Abstracts with Programs 42(5), p. 86

Zapata Peña, L., Ibáñez Estévez, J.J., González Urquijo, J., 1997. El yacimiento de la cueva de Kobaederra (Oma, Kortezubi, Bizkaia). Resultados preliminares de las campañas de excavación 1995-97. Munibe (Antropol.-Arkeol.) 49, 51-63. 